\title{
Exchange Rate Regimes in Central, Eastem, and Southeastem Europe: A Euro Bloc and a Dollar Bloc?
}

\author{
Slavi T. Slavov ${ }^{1+}$ \\ ${ }^{1}$ International Monetary Fund
}

\begin{abstract}
There are 13 countries in Central, Eastern, and Southeastern Europe (CESEE) with floating exchange rate regimes, de jure. This paper uses the framework pioneered by Frankel and Wei (1994) and extended in Frankel and Wei (2008) to show that most of them have been tracking either the euro or the US dollar in recent years. Eight countries, all of them current or aspiring EU members, track the euro. Of the five countries keying on the US dollar in various degrees, all but one belong to the Commonwealth of Independent States. The study shows that the extent to which each country's currency tracks the euro (or the dollar) is correlated with the structure of its external trade and finance. However, some countries appear to track the euro or US dollar to an extent that appears inconsistent with inflation targeting, trade or financial integration, or the extent of business cycle synchronization. The phenomenon is particularly pronounced among the euro bloc countries in Emerging Europe, which may be deliberately gravitating around the euro in anticipation of eventually joining the euro area.
\end{abstract}

Keywords: Central, Eastern and Southeastern Europe, Exchange rate regimes, Fixed versus floating, De jure versus De facto

\section{Introduction}

Over the past several decades, an increasing number of countries have started running floating exchange rate regimes, at least de jure. However, Calvo and Reinhart $(2002,2005)$ showed that many of these countries appear to actively limit exchange rate fluctuations. Thus, there is a discrepancy between de jure and de facto. The authors labeled this behavior "fear of floating" and illustrated its pervasiveness around the world.

This study investigates the exchange rate flexibility in Central, Eastern, and Southeastern

\footnotetext{
+Corresponding Author: Slavi T. Slavov

Senior Economist, International Monetary Fund, 700 19th Street NW, Washington, DC 20431, Tel: 202-623-6983, Email: sslavov@imf.org
}

Acknowledgements: I am grateful to Min Song for his superb research assistance. For constructive comments and ideas, I am indebted to Ezequiel Cabezon, Ernesto Crivelli, Guido Della Valle, Nicolas End, Jeffrey Frankel, Daniel Garcia-Macia, Swarnali Hannan, Kareem Ismail, Jens Reinke, James Roaf, Anita Tuladhar, Johannes Wiegand, an anonymous referee, as well as seminar participants at the IMF, the Bulgarian Macroeconomics Association, the American University in Bulgaria, and Pomona College. 
Europe (CESEE). Out of 22 countries in Emerging Europe, nine have officially given up exchange rate flexibility altogether by entering the euro area (Estonia, Latvia, Lithuania, Slovakia, and Slovenia), euroizing unilaterally (Kosovo and Montenegro), or establishing a currency board (Bosnia and Herzegovina, and Bulgaria). That leaves 13 countries with flexible exchange rates, at least de jure: Albania, Belarus, Croatia, the Czech Republic, Hungary, Moldova, North Macedonia, Poland, Romania, Russia, Serbia, Turkey, and Ukraine. Table 1 below summarizes the de jure exchange rate regimes of these 13 countries between 2008 and 2014, as reported by the IMF's Annual Report on Exchange Arrangements and Exchange Restrictions (AREAER). A higher numerical score in the table is associated with a more flexible exchange rate regime. Except for Belarus in 2008 2010, the lowest numerical score in Table 1 is 7 (corresponding to "managed floating with no pre-determined path for the exchange rate"). The median in each year is 9 ("floating"). The mean is similar, and the cross-section standard deviation is exceptionally low.

Table 1. De Jure exchange rate regimes in 13 CESEE countries, 2008 2014

\begin{tabular}{lccccccc}
\hline & $\mathbf{2 0 0 8}$ & $\mathbf{2 0 0 9}$ & $\mathbf{2 0 1 0}$ & $\mathbf{2 0 1 1}$ & $\mathbf{2 0 1 2}$ & $\mathbf{2 0 1 3}$ & $\mathbf{2 0 1 4}$ \\
\hline Albania & 10 & 10 & 10 & 10 & 10 & 10 & 10 \\
Belarus & 3 & 3 & 3 & 7 & 7 & n.a. & 7 \\
Croatia & 9 & 7 & 7 & 7 & 7 & 7 & 7 \\
Czech Republic & 10 & 9 & 9 & 9 & 9 & 9 & 9 \\
Hungary & 10 & 10 & 10 & 10 & 10 & 10 & 10 \\
Moldova & 9 & 9 & 9 & 9 & 9 & 9 & 9 \\
North Macedonia & 7 & 9 & 9 & 9 & 9 & 9 & 9 \\
Poland & 10 & 10 & 10 & 10 & 10 & 10 & 10 \\
Romania & 7 & 7 & 7 & 7 & 7 & 7 & 7 \\
Russia & 8 & 8 & 8 & 8 & 8 & 8 & 9 \\
Serbia & 9 & 9 & 7 & 9 & 9 & 9 & 9 \\
Turkey & 10 & 10 & 10 & 10 & 10 & 10 & 10 \\
Ukraine & 9 & 9 & n.a. & n.a. & n.a. & n.a. & n.a. \\
\hline Median & $\mathbf{9 . 0}$ & $\mathbf{9 . 0}$ & $\mathbf{9 . 0}$ & $\mathbf{9 . 0}$ & $\mathbf{9 . 0}$ & $\mathbf{9 . 0}$ & $\mathbf{9 . 0}$ \\
Mean & $\mathbf{8 . 5}$ & $\mathbf{8 . 5}$ & $\mathbf{8 . 3}$ & $\mathbf{8 . 8}$ & $\mathbf{8 . 8}$ & $\mathbf{8 . 9}$ & $\mathbf{8 . 8}$ \\
Standard deviation & $\mathbf{2 . 0}$ & $\mathbf{1 . 9}$ & $\mathbf{2 . 1}$ & $\mathbf{1 . 2}$ & $\mathbf{1 . 2}$ & $\mathbf{1 . 1}$ & $\mathbf{1 . 2}$ \\
\hline
\end{tabular}

(Note) 1 = No separate legal tender; 2 = Currency board; $3=$ Conventional peg; $3.5=$ Conventional peg to a composite; $4=$ Stabilized arrangement; $5=$ Crawling peg; $6=$ Crawl-like arrangement; $7=$ Managed floating with no pre-determined path for the exchange rate; $8=$ Other managed arrangement; $9=$ Floating; $10=$ Free floating.

(Source) IMF's Annual Report on Exchange Arrangements and Exchange Restrictions.

Table 2 below summarizes the de facto exchange rate regimes of these 13 countries between 2008 and 2014, as reported by the AREAER. A comparison of Tables 1 and 2 reveals there is more dispersion in Table 2 and the mean is somewhat lower. There are some substantial 
differences for some countries and some years in both directions. For example, North Macedonia's exchange rate regime is classified as "floating" de jure, but as a "stabilized arrangement" de facto. On the other hand, Romania's exchange rate regime is classified as "managed floating" in Table 1 and as "floating" in Table 2. However, once again, the median in each year is 9 ("floating").

Table 2. De Facto exchange rate regimes in 13 CESEE countries, 2008 2014

\begin{tabular}{|c|c|c|c|c|c|c|c|}
\hline & 2008 & 2009 & 2010 & 2011 & 2012 & 2013 & 2014 \\
\hline Albania & 9 & 9 & 9 & 9 & 9 & 9 & 9 \\
\hline Belarus & 7 & 7 & 4 & 8 & 8 & 6 & 6 \\
\hline Croatia & 8 & 4 & 6 & 6 & 6 & 6 & 6 \\
\hline Czech Republic & 10 & 10 & 10 & 10 & 10 & 8 & 4 \\
\hline Hungary & 9 & 9 & 9 & 9 & 9 & 9 & 9 \\
\hline Moldova & 9 & 9 & 9 & 9 & 9 & 9 & 9 \\
\hline North Macedonia & 4 & 4 & 4 & 4 & 4 & 4 & 4 \\
\hline Poland & 10 & 10 & 10 & 10 & 10 & 10 & 10 \\
\hline Romania & 9 & 9 & 9 & 9 & 9 & 9 & 9 \\
\hline Russia & 8 & 8 & 8 & 8 & 8 & 8 & 9 \\
\hline Serbia & 9 & 9 & 9 & 9 & 9 & 9 & 9 \\
\hline Turkey & 9 & 10 & 9 & 9 & 9 & 9 & 9 \\
\hline Ukraine & 8 & 8 & 4 & 4 & 4 & 9 & 9 \\
\hline Median & 9.0 & 9.0 & 9.0 & 9.0 & 9.0 & 9.0 & 9.0 \\
\hline Mean & 8.4 & 8.2 & 7.7 & 8.0 & 8.0 & 8.1 & 7.8 \\
\hline Standard deviation & 1.6 & 2.0 & 2.3 & 2.0 & 2.0 & 1.7 & 2.1 \\
\hline
\end{tabular}

(Note) 1 = No separate legal tender; 2 = Currency board; $3=$ Conventional peg; $3.5=$ Conventional peg to a composite; 4 = Stabilized arrangement; $5=$ Crawling peg; $6=$ Crawl-like arrangement; $7=$ Managed floating with no pre-determined path for the exchange rate; $8=$ Other managed arrangement; $9=$ Floating; $10=$ Free floating.

(Source) IMF's Annual Report on Exchange Arrangements and Exchange Restrictions.

The remaining paper is organized as follows: Section II of this paper reviews the extant literature related to the subject of this research.

Section III presents stylized facts and statistical analysis on monthly data for 1999 2015. First, for each of the 13 countries in Emerging Europe, the section compares the monthly volatility in the country's exchange rate (with the US dollar or the euro) to the monthly volatility in its consumer price index (CPI) and gross international reserves.

Second, a simple empirical model first proposed in Frankel and Wei (1994) and later extended in Frankel and Wei (2008) is estimated to determine whether a country is pursuing a fixed exchange rate regime and, if so, what currency the country is pegging to. The model is first estimated for the entire sample period, and then re-estimated using rolling 36-month regressions for each country to explore the extent to which exchange rate regimes have evolved from 
1999 to 2015.

Third, two robustness checks allow for an asymmetric response to appreciations and depreciations of major currencies and expand the definition of "exchange market pressure" to include the volatility of interest rates.

To summarize the results, section III reveals that many of the 13 CESEE countries exhibited limited exchange rate flexibility during the examined period and divided themselves neatly into a euro bloc and a dollar bloc. That is, the exchange rate regimes of most of these countries can be approximated quite well by a soft peg to a currency basket dominated by the euro or the US dollar.

Section IV investigates the reasons behind exchange rate stability in Emerging Europe, specifically whether this stability is natural or policy driven. The section explores four possible explanations for limited exchange rate flexibility in CESEE. First, it could be a natural manifestation of inflation targeting when the exchange rate pass-through is high. However, between 2013 and 2015, many countries in Emerging Europe with de jure flexible exchange rate regimes consistently undershot their inflation targets.

Second, exchange rate stability could be a consequence of trade integration. However, most CESEE countries appear to stabilize their bilateral exchange rates with the US dollar or the euro to an extent inconsistent with merely stabilizing their trade-weighted nominal effective exchange rates (NEERs).

Third, limited exchange rate flexibility could be the product of pervasive liability dollarization (or euroization). Whereas the data confirms a strong empirical link between the two phenomena in Emerging Europe, liability dollarization is not a natural driver of exchange rate stability. Rather, it explains why limiting the exchange rate flexibility is a sensible policy choice.

Fourth, a stable exchange rate could be the natural product of business cycle synchronization. Though this appears to be a plausible explanation for the three Central European inflation targeters (the Czech Republic, Hungary, and Poland), it is less so for the five Balkan countries (Albania, Croatia North Macedonia, Romania, and Serbia).

To summarize, the extent to which each country's currency tracks the euro or the US dollar is correlated with the currency structure of its external trade and finance. However, some countries appear to track the euro or US dollar to an extent that appears inconsistent with inflation targeting, trade or financial integration, or the extent of business cycle synchronization. The phenomenon is particularly pronounced among the countries in the CESEE euro bloc, which may be deliberately gravitating around the euro in anticipation of eventually joining the euro area.

Finally, Section V concludes the paper and offers ideas for future research. 


\section{Literature Review}

Calvo and Reinhart $(2002,2005)$ singled out insufficient policy credibility as the main driver behind "fear of floating" and the associated procyclical policies. They analytically illustrated how loss of policy credibility (triggered by sharp exchange rate movements) could turn into loss of market access, which, in turn, could induce an economic contraction. With these considerations in mind, the authors argued that limited exchange rate flexibility might be a sensible policy choice for some countries, including the transition economies in the euro area's periphery.

Frankel and Wei (1994) used a precursor of the econometric equation used in this paper to investigate the emergence of a yen currency bloc in East Asia. The empirical technique they used estimated the implicit de facto currency weights under the hypothesis of a basket peg with little flexibility. The authors found little empirical support for the yen bloc hypothesis and concluded that East Asian countries remained strongly linked to the US dollar. The authors also noted the emergence of a currency bloc centered on the Deutsche Mark in Europe.

Frankel and Wei (2008) augmented the empirical model employed in Frankel and Wei (1994) by adding a technique used by others to estimate the de facto degree of exchange rate flexibility. They applied the empirical model to over 20 currencies from 1980 to 2007 (including the Russian ruble) and found substantial discrepancies between de jure and de facto exchange rate regimes in some cases.

D'Adamo (2009) estimated the Frankel and Wei (2008) model for many European countries outside EMU, including several countries in Emerging Europe. The author found that the move toward inflation targeting in many of those countries led to higher exchange rate flexibility, but less than what one might have expected based on the non-European benchmark floaters. In addition, inflation targeters in Europe seemed to have emphasized exchange rate stabilization vis-à-vis the euro, which has gradually turned into an informal anchor for most European currencies. Note, however, that the paper's sample ends in 2009, and it covers only 4 of the 13 CESEE countries covered in the current paper: the Czech Republic, Hungary, Poland, and Romania.

Taking stock of the literature, the main contribution of the current paper is the comprehensive examination of exchange rate regimes in Emerging Europe in the aftermath of the 2008 Global Financial Crisis using the analytical framework pioneered by Frankel and Wei (2008). Whereas other sources have previously studied de facto exchange rate regimes in the region, their data samples extend only to 2009, or cover only a handful of countries in Emerging Europe. Moreover, though other papers typically focus on the age-old question of "fix or float," this paper extends the analysis to "which currency (or basket of currencies) are countries fixing to?" 


\section{Documenting Limited Exchange Rate Flexibility in Emerging Europe}

\section{A. Stylized facts}

Figure 1 presents empirical evidence on the monthly volatility of a country's CPI and its exchange rate vis-à-vis the euro or the US dollar (whichever is less volatile). The figure covers 1999 to 2015 and the 13 countries in Emerging Europe with de jure floating exchange rates. As a benchmark, the figure includes South Africa, one emerging market with unquestioned credentials as a free-floating inflation targeter. One would expect that such a country would have a volatile exchange rate and a stable CPI-a well-known empirical regularity in floating exchange rate regimes.1) This is, indeed, the case for South Africa. By comparison, exchange rates are somewhat less volatile in the Czech Republic, Hungary, and Poland-three CESEE countries with the same monetary and exchange rate regime. The contrast with South Africa is even more dramatic for the five Balkan countries in the second column of Figure 1: Not only Croatia and North Macedonia (both of which are well known to be stabilizing their euro exchange rates de facto if not de jure), but also Albania, Romania, and Serbia, all of which are inflation-targeting floaters de jure. The third column in Figure 1 covers the remaining five countries in Emerging Europe. Turkey and Russia come close to matching South Africa in terms of the relative volatility of their exchange rate. In contrast, Belarus, Moldova, and Ukraine have much more stable currencies, apart from the occasional bursts of exchange rate volatility, corresponding to large depreciation episodes.

Table 3 summarizes the data presented in Figure 1 by reporting the ratio of the standard deviation of the monthly change in the exchange rate to the standard deviation of the monthly change in the CPI. That ratio is 9.5 for South Africa and ranges from 1.2 to 6.7 for the 13 CESEE countries with de jure floating exchange rates. Note that the ratio ranges from 3.5 to 6.7 for the Czech Republic, Hungary, Poland, and Russia. In contrast, the ratio ranges from

Table 3. Ratio of the standard deviation of the monthly change in the exchange rate with US dollar or euro and the standard deviation of the monthly change in the CPI for 13 CESEE countries and South Africa (1999 2015)

\begin{tabular}{c|c|c|c|c|c}
\hline Country & $\frac{\sigma_{\epsilon}}{\sigma_{\pi}}$ & Country & $\frac{\sigma_{\epsilon}}{\sigma_{\pi}}$ & Country & $\frac{\sigma_{\epsilon}}{\sigma_{\pi}}$ \\
\hline South Africa & 9.5 & Albania & 1.3 & Belarus & 2.2 \\
Czech Republic & 3.5 & Croatia & 2.6 & Moldova & 2.4 \\
Hungary & 4.3 & North Macedonia & 1.2 & Russia & 4.2 \\
Poland & 6.7 & Serbia & 2.0 & Turkey & 3.1 \\
\hline
\end{tabular}

(Source) IMF's International Financial Statistics database.

1) See Mussa (1986), among others. 
1.2 to 3.1 for the remaining countries in Emerging Europe (with Ukraine as a special case, due to infrequent, but large, depreciations).

Figure 1. Monthly changes in the CPI and the exchange rate with US dollar or euro for 13 CESEE countries and South Africa (1999 2015)

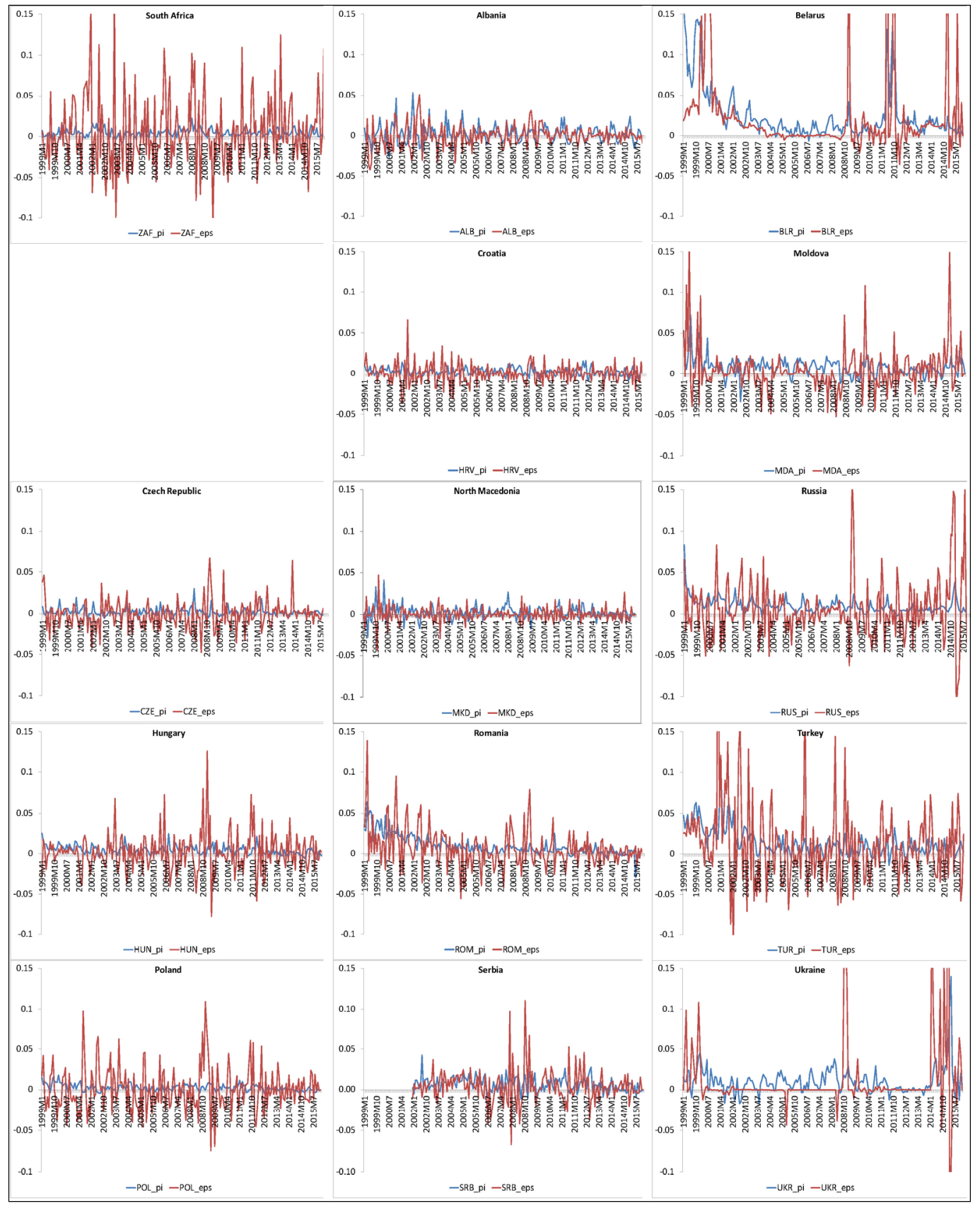

(Source) IMF's International Financial Statistics database. 
Figure 2 reports further summary statistics on the 13 CESEE floaters plus South Africa. It plots the standard deviation of the monthly change in gross international reserves (relative to reserve money) against the standard deviation of the monthly percentage change in each country's exchange rate vis-à-vis the euro or the US dollar (whichever is lower) for 1999 2015.

The upward-sloping line in the figure has a slope of unity. Note that the only country that lies below the 45-degree line-a somewhat arbitrary benchmark-is South Africa. Because all 13 countries in Emerging Europe lie above this line, gross international reserves are more volatile than their euro or dollar exchange rates. This is further suggestive evidence that many of these CESEE countries might be showing signs of "fear of floating." For many of these countries, the stock of international reserves appears to play a relatively more important role in absorbing shocks to the balance of payments than the exchange rate.

Figure 2. Volatility of gross international reserves versus exchange rate volatility for 13 CESEE countries and South Africa (monthly data, 1999 2015)

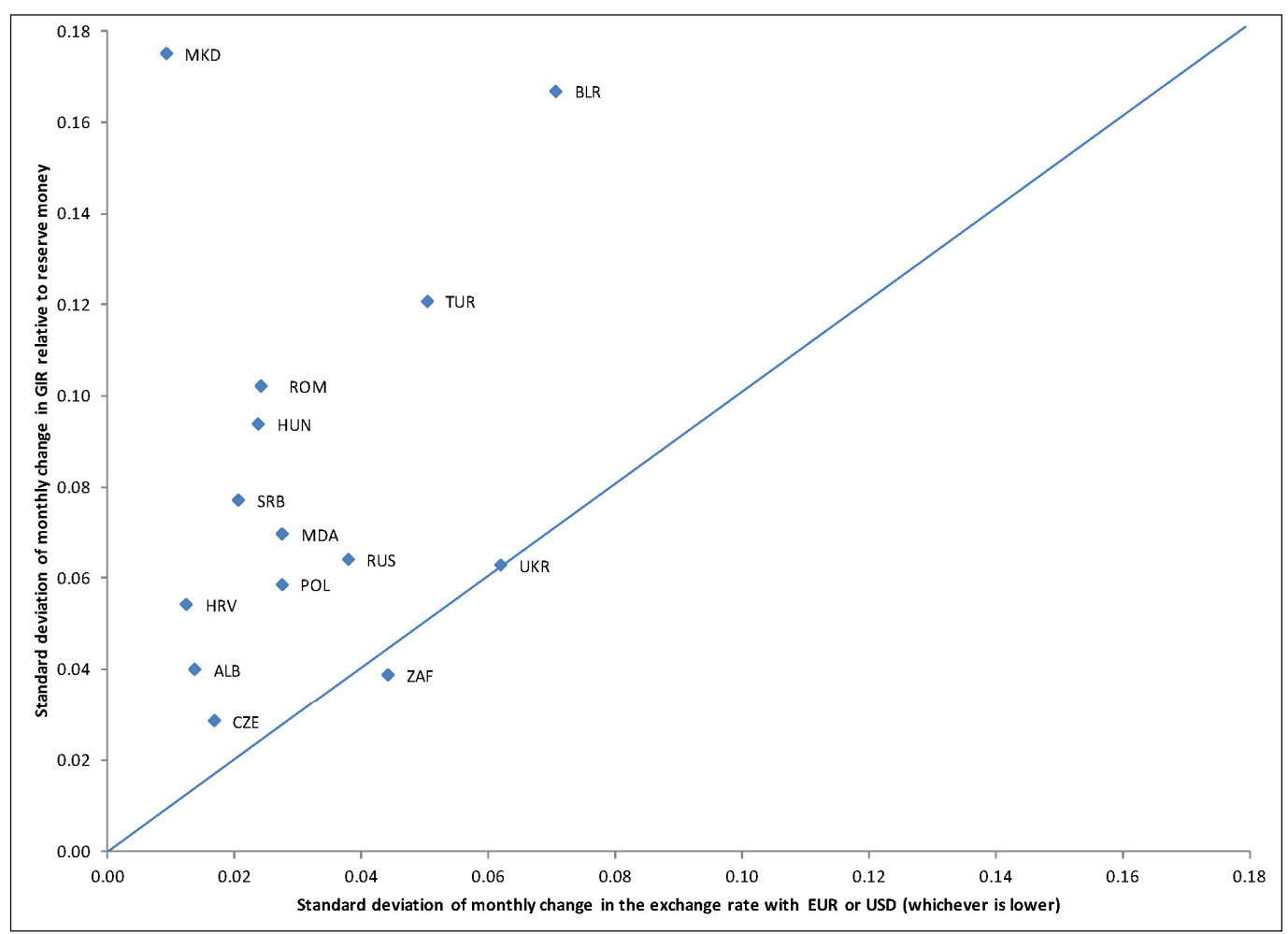

(Source) IMF's International Financial Statistics database.

\section{B. The empirical model and the data}

Frankel and Wei (1994) offer a simple way to identify a country's de facto exchange rate 
regime, later extended in Frankel and Wei (2008). Their methodology proceeds in two intuitive steps. First, is a country pursuing a fixed or floating exchange rate regime? Second, if the country is pegging, what currency (or basket of currencies) is it pegging to? The regression equation estimated here is similar to the one estimated in Frankel and Wei (2008), with one important difference discussed below. Taking Albania as an illustrative example:

$$
\begin{aligned}
& \varepsilon_{(A L L / S D R)}=\beta_{0}+\beta_{1}+\beta_{2} \varepsilon_{U S D / S D R}+\beta_{3} \varepsilon_{E U R / S D R}+\beta_{4} \varepsilon_{G B P / S D R}+u, \\
& \text { where EMP } \equiv-\frac{\triangle G I R}{R M}
\end{aligned}
$$

Above, $\varepsilon_{A L L / S D R}$ denotes the percentage change in the Albanian lek-SDR exchange rate; and three of the independent variables are defined similarly. EMP stands for "exchange market pressure." GIR and $R M$ denote gross international reserves and reserve money, respectively.

Estimating $\beta_{1}$ would answer the first question above by revealing how flexible the exchange rate regime truly is. EMP measures the exchange market pressure on a country's currency, as reflected by the change in gross international reserves normalized by reserve money. If there is a positive shock to domestic currency demand, it should manifest either as an exchange rate appreciation or as an increase in international reserves (thus, either way, the EMP variable goes down). $\beta_{1}$ measures the extent to which market pressure on the currency is reflected in the exchange rate versus the stock of reserves. If the Albanian lek is completely fixed to a currency, we would expect to find that $\beta_{1}$ is zero, that is, shocks to demand for the currency are reflected in the stock of international reserves rather than the exchange rate. On the contrary, if the lek is freely floating, we would expect to find a higher (and statistically significant) value for $\beta_{1}$, indicating that exchange market shocks are absorbed mostly by the exchange rate rather than by the stock of reserves. 2),3)

Note that $\beta_{1}$ is intended to measure only correlation, rather than any causal relationship between the stock of international reserves and the exchange rate. Therefore, $\beta_{1}$ measures only the relative "division of labor" between international reserves and the exchange rate in absorbing shocks to the demand for domestic currency.

Regarding the $S D R$, we examine the exchange rate between the domestic currency and an appropriate numéraire currency to explore its degree of co-movement with the exchange rate

2) Frankel and Wei (2008) defined $E M P$ as $\varepsilon_{A L L / S D R}-\frac{\triangle G I R}{R M}$, which creates an endogeneity problem, as $\varepsilon_{A L L / S D R}$ appears on both sides of the equation and biases coefficient estimates. The authors' solution to this problem was instrumental variable (IV) estimates for EMP. However, their preferred instrument (commodity prices) is not a good fit for most CESEE countries.

3) Note that $\beta_{1}$ is indeterminate for the extreme case of a pure float under which GIR is zero (or constant). Though this is a valid concern in theory, it is not a problem in practice, as there is always some volatility in each country's stock of GIR. 
between the euro (or the US dollar) and the same numéraire. The $S D R$ is a good candidate for a numéraire because, by virtue of being a basket of the major free-floating currencies, it floats freely against all of them.4)

If the Albanian lek is indeed floating against the euro, there should be little to no correlation between the lek-SDR and the euro-SDR exchange rates, and we expect to find $\beta_{3} \approx 0$. If the lek is completely fixed to the euro, the two exchange rates should be perfectly correlated, so that $\beta_{3}=1$. By including the US dollar and the British pound, we allow for the possibility of the lek being pegged to one of these other major currencies, rather than the euro. We also explore the possibility that the Albanian authorities are stabilizing the exchange rate against a basket of these three currencies. In this case, $\beta_{2}, \beta_{3}$, and $\beta_{4}$ would measure the basket weights on each currency. Thus, these regression coefficients would answer the second question above ("If pegging, what currency, or basket of currencies, is the country pegging to?'). Finally, $\beta_{0}$ captures the domestic currency's time trend, that is, its tendency to appreciate or depreciate over time.

Equation (1) will be estimated using monthly data from January 1999 to December 2015. The data source for all variables is the IMF's International Financial Statistics database. For all reported results, observations associated with annual inflation exceeding 20 percent ${ }^{5)}$ were dropped to limit the sample to periods during which the sample countries had a time-consistent and credible monetary policy framework in place.

\section{The results}

To provide a useful benchmark, Equation (1) was first estimated for Bulgaria (a CESEE country with a currency board with the euro) and South Africa (an inflation-targeting free-floater). The model correctly identifies both countries' exchange rate regimes. In Table 4, Bulgaria's estimated weight on the euro is unity, whereas all other coefficients are essentially zero. The adjusted $R^{2}$ is remarkably high. In contrast, South Africa's adjusted $R^{2}$ is extremely low. The only statistically significant regression coefficients are the constant (which indicates a tendency for the rand to depreciate over time by about 1 percent per month) and the EMP (which indicates that the country's exchange rate plays an important role as a shock absorber). Note that the estimated weight on the euro is only marginally statistically significant.

When Equation (1) was estimated for the 13 countries in Emerging Europe with de jure floating exchange rates, they divided themselves neatly into two groups: a euro bloc and a

4) Other authors have used the Swiss franc as the numéraire currency. However, between September 2011 and January 2015, the franc did not float freely against the euro, as Switzerland's monetary authorities embarked on various initiatives to curb its appreciation against the euro. In general, other authors have demonstrated that regression results are fairly robust to the choice of a numéraire currency.

5) Specifically, month $t$ was dropped if the month $t+12$ annual inflation rate exceeded 20 percent. Frankel and Wei (2008) used a higher threshold of 40 percent. The IMF's World Economic Outlook projections were used for the last few months of the sample. 
dollar bloc. Tables 5 and 6 below present the estimation results for the eight countries that were found to track the euro very closely. All of them are either current or aspiring EU members. Table 5 reports results for the five Balkan countries in the sample, whereas Table 6 focuses on three Central European inflation targeters. Bulgaria and South Africa are also reported in both tables, for ease of reference. Thus, Tables 5 and 6 attempt to place these eight countries on a continuum between the two extremes of a hard peg (Bulgaria) and a free float (South Africa).

Table 4. Regression results for bulgaria and South Africa, 1999 2015

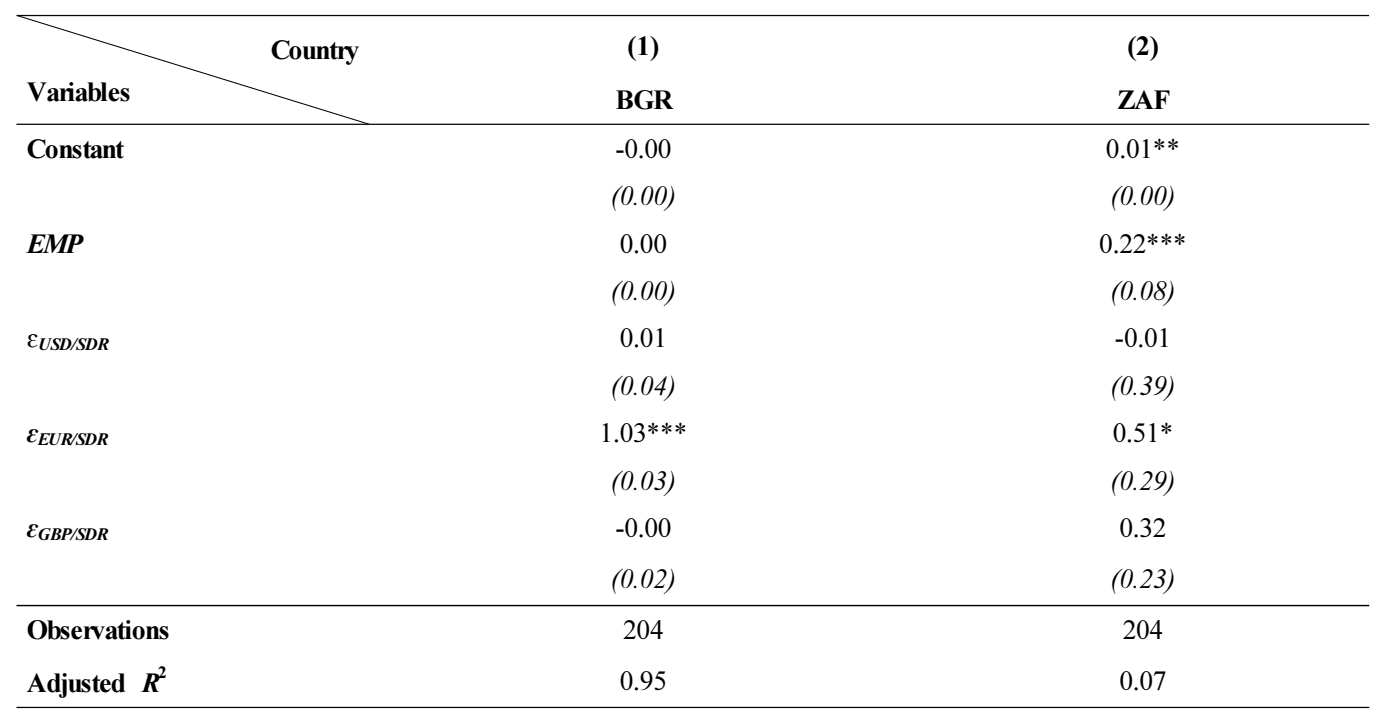

(Notes) Columns ( 1 and 2) estimate Equation (1) in the main text of the paper. The dependent variable is the percentage change in the country's exchange rate with the $S D R$. EMP is defined in Equation (2) in the main text of the paper. $\varepsilon_{U S D / S D R}$ is the percentage change in the US dollar's exchange rate with the $S D R$. The remaining independent variables are defined similarly for the euro and the British pound. Robust standard errors are reported in parentheses. $* * *, * *$, and $*$ denote statistical significance at the $1 \%, 5 \%$, and $10 \%$ level, respectively.

In Table 5, the estimated coefficient on the EMP variable is typically close to zero, with a median value of 0.03 , which is much lower than South Africa's 0.22. In these five countries, shocks to demand for the domestic currency tend to be reflected in the stock of international reserves and not in the exchange rate. This is the reverse of what one should expect to find in a freely floating exchange rate regime. The estimated coefficient on the euro is always highly statistically significant and close to one for all countries, with a median value of 0.93 . The median weights on the US dollar and the British pound are close to zero, although they are statistically significant in a few cases. The median adjusted $R^{2}$ is 0.57 and somewhat higher for Croatia and North Macedonia, two countries known to stabilize their currencies. Overall, these five countries mostly resemble Bulgaria than South Africa.

Note that what establishes limited exchange rate flexibility in Table 5 is not any exchange rate comovement with the euro. Rather, it is the volatility of the country's SDR exchange rate 
relative to the volatility of gross international reserves (as measured by the EMP regression coefficient).

Table 5. Regression results for five balkan countries, 1999 2015

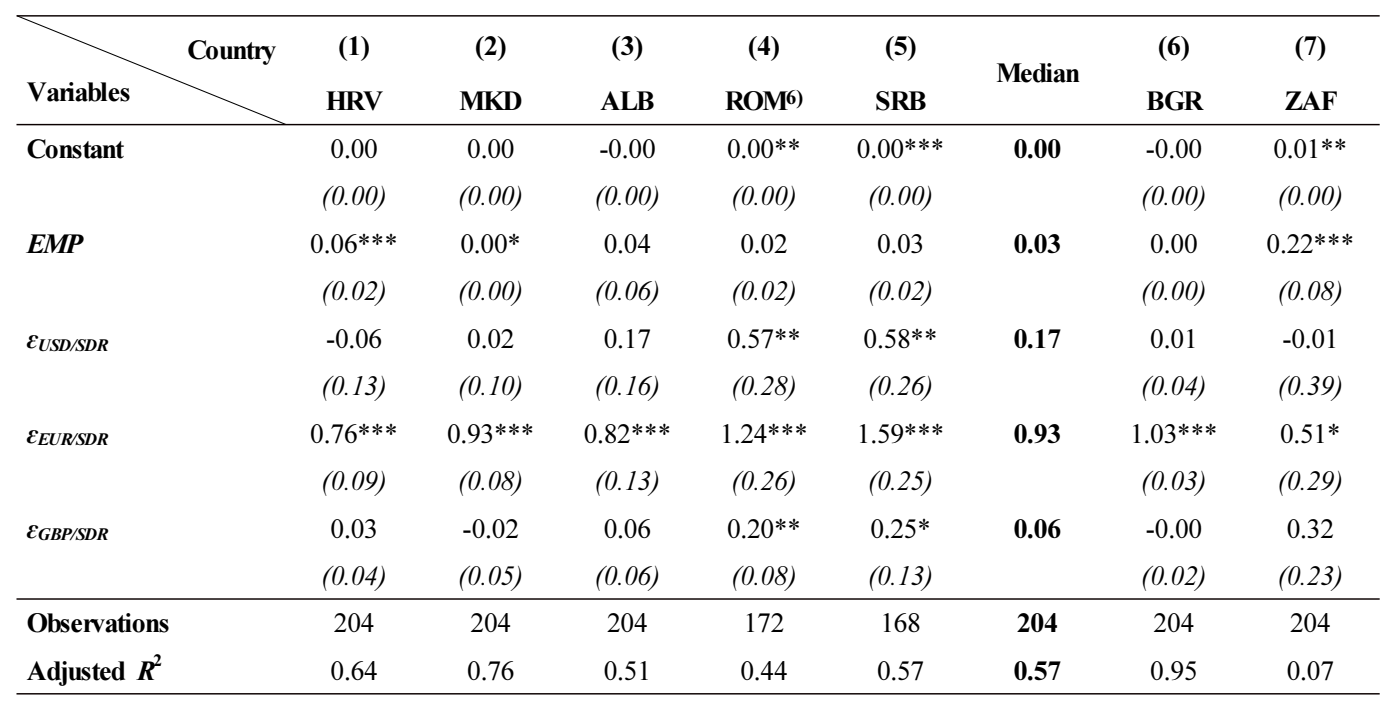

(Notes) Columns ( 1 to 7 ) estimate Equation (1) in the main text of the paper. The dependent variable is the percentage change in the country's exchange rate with the $S D R$. EMP is defined in Equation (2) in the main text of the paper. $\varepsilon_{U S D / S D R}$ is the percentage change in the US dollar's exchange rate with the SDR. The remaining independent variables are defined similarly for the euro and the British pound. Robust standard errors are reported in parentheses. $* * *, * *$, and $*$ denote statistical significance at the $1 \%, 5 \%$, and $10 \%$ level, respectively.

Table 6 reports results for the three Central European inflation targeters. The estimated coefficient on the EMP variable is always close to zero, with a median value of 0.00 , and is only marginally statistically significant in Poland. Once again, shocks to demand for the domestic currency are mostly reflected in the stock of international reserves, rather than the exchange rate. The estimated coefficient on the euro is always highly statistically significant, with a median value of 1.04, which exceeds the median in Table 5. While Poland's adjusted $R^{2}$ is only 0.35 , the median is 0.52 , which is somewhat lower than in Table 5 , but significantly higher than in South Africa.

Table 7 below presents the estimation results for the five countries that were found to track the dollar. Except for Turkey, all others belong to the Commonwealth of Independent States. For Belarus, Moldova, and Ukraine, Equation (1) was augmented by also including $\varepsilon_{R U B / S D R}$, the exchange rate of the Russian ruble against the $S D R$, to allow for the possibility that these three countries track Russia's currency.

Empirical estimates for Russia and (to a lesser extent) Moldova come close to matching

6) The results are unchanged for Romania if the sample is restricted to the period after 2005, when the country formally adopted an inflation-targeting framework. 
Table 6. Regression results for three central european inflation targeters, 1999 2015

\begin{tabular}{|c|c|c|c|c|c|c|}
\hline Country & $\begin{array}{c}\text { (1) } \\
\text { CZE }\end{array}$ & $\begin{array}{c}(2) \\
\text { HUN }\end{array}$ & $\begin{array}{c}\text { (3) } \\
\text { POL }\end{array}$ & Median & $\begin{array}{c}(4) \\
\text { BGR }\end{array}$ & $\begin{array}{c}\text { (5) } \\
\text { ZAF }\end{array}$ \\
\hline \multirow[t]{2}{*}{ Constant } & -0.00 & 0.00 & 0.00 & 0.00 & -0.00 & $0.01 * *$ \\
\hline & $(0.00)$ & $(0.00)$ & $(0.00)$ & & $(0.00)$ & $(0.00)$ \\
\hline \multirow[t]{2}{*}{ EMP } & -0.05 & 0.00 & $0.06^{*}$ & 0.00 & 0.00 & $0.22 * * *$ \\
\hline & $(0.08)$ & $(0.02)$ & $(0.03)$ & & $(0.00)$ & (0.08) \\
\hline \multirow[t]{2}{*}{$\varepsilon_{U S D / S D R}$} & -0.22 & -0.00 & 0.15 & 0.00 & 0.01 & -0.01 \\
\hline & $(0.15)$ & $(0.26)$ & $(0.35)$ & & $(0.04)$ & (0.39) \\
\hline \multirow[t]{2}{*}{$\varepsilon_{E U R / S D R}$} & $0.98 * * *$ & $1.31 * * *$ & $1.04 * * *$ & 1.04 & $1.03 * * *$ & $0.51 *$ \\
\hline & (0.13) & $(0.28)$ & $(0.27)$ & & (0.03) & (0.29) \\
\hline \multirow[t]{2}{*}{$\varepsilon_{G B P / S D R}$} & 0.17 & $0.25 * *$ & $0.36^{* *}$ & 0.25 & -0.00 & 0.32 \\
\hline & (0.13) & $(0.10)$ & $(0.15)$ & & $(0.02)$ & (0.23) \\
\hline Observations & 204 & 196 & 204 & 204 & 204 & 204 \\
\hline Adjusted $R^{2}$ & 0.61 & 0.52 & 0.35 & 0.52 & 0.95 & 0.07 \\
\hline
\end{tabular}

(Notes) Columns ( 1 to 5 ) estimate Equation (1) in the main text of the paper. The dependent variable is the percentage change in the country's exchange rate with the SDR. EMP is defined in Equation (2) in the main text of the paper. $\varepsilon_{U S D / S D R}$ is the percentage change in the US dollar's exchange rate with the $S D R$. The remaining independent variables are defined similarly for the euro and the British pound. Robust standard errors are reported in parentheses. $* * *, * *$, and $*$ denote statistical significance at the $1 \%, 5 \%$, and $10 \%$ level, respectively.

Table 7. Regression results for the dollar bloc, 1999 2015

\begin{tabular}{|c|c|c|c|c|c|c|c|c|}
\hline Variables & $\begin{array}{c}(1) \\
\text { BLR }\end{array}$ & $\begin{array}{c}(2) \\
\text { MDA }\end{array}$ & $\begin{array}{c}\text { (3) } \\
\text { RUS }\end{array}$ & $\begin{array}{c}\text { (4) } \\
\text { TUR }\end{array}$ & $\begin{array}{c}\text { (5) } \\
\text { UKR }\end{array}$ & Median & $\begin{array}{c}\text { (6) } \\
\text { BGR }\end{array}$ & $\begin{array}{c}(7) \\
\text { ZAF }\end{array}$ \\
\hline \multirow[t]{2}{*}{ Constant } & $0.01 * * *$ & $0.00 * *$ & $0.01 * * *$ & 0.00 & $0.00 *$ & 0.00 & -0.00 & $0.01 * *$ \\
\hline & $(0.00)$ & $(0.00)$ & $(0.00)$ & $(0.00)$ & $(0.00)$ & & $(0.00)$ & $(0.00)$ \\
\hline \multirow[t]{2}{*}{$E M P$} & -0.02 & $0.08 * *$ & $0.15^{* *}$ & 0.08 & 0.04 & 0.08 & 0.00 & $0.22 * * *$ \\
\hline & $(0.01)$ & $(0.03)$ & $(0.06)$ & $(0.06)$ & $(0.04)$ & & $(0.00)$ & $(0.08)$ \\
\hline \multirow[t]{2}{*}{$\varepsilon_{U S D / S D R}$} & $1.02 * *$ & 0.33 & $0.57 *$ & $1.10^{* *}$ & $1.30 * * *$ & 1.02 & 0.01 & -0.01 \\
\hline & $(0.40)$ & $(0.27)$ & $(0.30)$ & $(0.48)$ & $(0.22)$ & & $(0.04)$ & $(0.39)$ \\
\hline \multirow[t]{2}{*}{$\varepsilon_{E U R S D R}$} & 0.54 & -0.09 & 0.53 & $1.02 * *$ & 0.21 & 0.53 & $1.03 * * *$ & $0.51 *$ \\
\hline & $(0.42)$ & $(0.17)$ & $(0.35)$ & $(0.42)$ & $(0.25)$ & & $(0.03)$ & $(0.29)$ \\
\hline \multirow[t]{2}{*}{$\varepsilon_{G B P / S D R}$} & $-0.27 * *$ & $-0.19^{*}$ & $0.33^{*}$ & 0.37 & $0.66^{* *}$ & 0.33 & -0.00 & 0.32 \\
\hline & $(0.12)$ & $(0.10)$ & $(0.19)$ & $(0.24)$ & $(0.26)$ & & $(0.02)$ & $(0.23)$ \\
\hline \multirow[t]{2}{*}{$\varepsilon_{R U B / S D R}$} & $0.67 * * *$ & $0.20 * *$ & & & 0.05 & 0.20 & & \\
\hline & $(0.15)$ & $(0.08)$ & & & $(0.09)$ & & & \\
\hline Observations & 126 & 191 & 190 & 158 & 156 & 158 & 204 & 204 \\
\hline Adjusted $R^{2}$ & 0.59 & 0.21 & 0.12 & 0.07 & 0.41 & 0.21 & 0.95 & 0.07 \\
\hline
\end{tabular}

(Notes) Columns ( 1 to 7 ) estimate Equation (1) in the main text of the paper. The dependent variable is the percentage change in the country's exchange rate with the SDR. EMP is defined in Equation (2) in the main text of the paper. $\varepsilon_{U S D / S D R}$ is the percentage change in the US dollar's exchange rate with the SDR. The remaining independent variables are defined similarly for the euro, the British pound, and the Russian ruble. Robust standard errors are reported in parentheses. ${ }^{* *},{ }^{* *}$, and $*$ denote statistical significance at the $1 \%, 5 \%$, and $10 \%$ level, respectively. 
those for South Africa. The EMP coefficients are statistically significant and relatively large. The adjusted $R^{2}$ is low in both cases. Both countries place some substantial weight on other currencies: the US dollar in Russia's case and the ruble in Moldova's. In sum, while Moldova's case is less clear-cut, Russia is a clear example of a country whose exchange rate plays an important role as a shock absorber, relative to the stock of gross international reserves. Hence, the model identifies it as a clear floater, even though it also appears to track the US dollar to some degree.

Turning to Belarus and Ukraine, the estimated coefficients on the EMP variable are small and statistically insignificant. Shocks to demand for the domestic currency are mostly reflected in the stock of international reserves, rather than the exchange rate. The estimated coefficient on the US dollar is highly statistically significant and close to unity in each country. The adjusted $R^{2}$ is significantly higher for these two countries than for Russia and Moldova (or South Africa).

The model generates similar (but somewhat noisier) results for Turkey. The estimated EMP coefficient is statistically insignificant and the estimated coefficients on the US dollar and the euro are both high and significant. However, the adjusted $R^{2}$ is exceptionally low.

Overall, Table 7 suggests that, though most of these five countries appear to track the US dollar to varying extents, Russia comes closer to having a freely floating currency than any other country in Emerging Europe.

One might criticize Tables 5 to 7 for their implicit assumption that these 13 countries maintained their exchange rate regimes without any changes at all for the entire 17-year sample period. It would be interesting to see if and how their exchange rate regimes have evolved since 1999. Therefore, Figures 3 to 5 report the estimates from rolling 36-month regressions for the 13 countries in Emerging Europe. The data point on the far-left corner in each figure corresponds to the 36-month period starting in January 1999 and ending in December 2001. The 36-month horizon is a balancing act. On the one hand, we need to have enough degrees of freedom to estimate the exchange rate regime. On the other hand, we want to allow for exchange rate regimes to evolve over time. To reduce clutter, the figures report only the median weight on the euro (or the US dollar), the median EMP coefficient, and the median adjusted $R^{2}$ for each 36-month period.7)

Figure 3 covers the five Balkan countries (Albania, Croatia, North Macedonia, Romania, and Serbia) and shows that the exchange rate regimes shifted marginally around 2008. The median euro weight started out between 0.6 and 0.8 , but jumped to unity in 2008, and has fallen somewhat since then. The median adjusted $R^{2}$ followed a similar path. The median EMP coefficient was close to zero throughout the sample period, apart from a few blips (for example, during the Global Financial Crisis and its immediate aftermath). All these findings point to

7) Because I focus on medians across countries, the restriction on annual inflation to be lower than 20 percent was dropped. 
Figure 3. Median basket weight on the EUR, median EMP, and median adjusted $R^{2}$ from 36-month rolling regressions for five balkan countries, 1999 2015

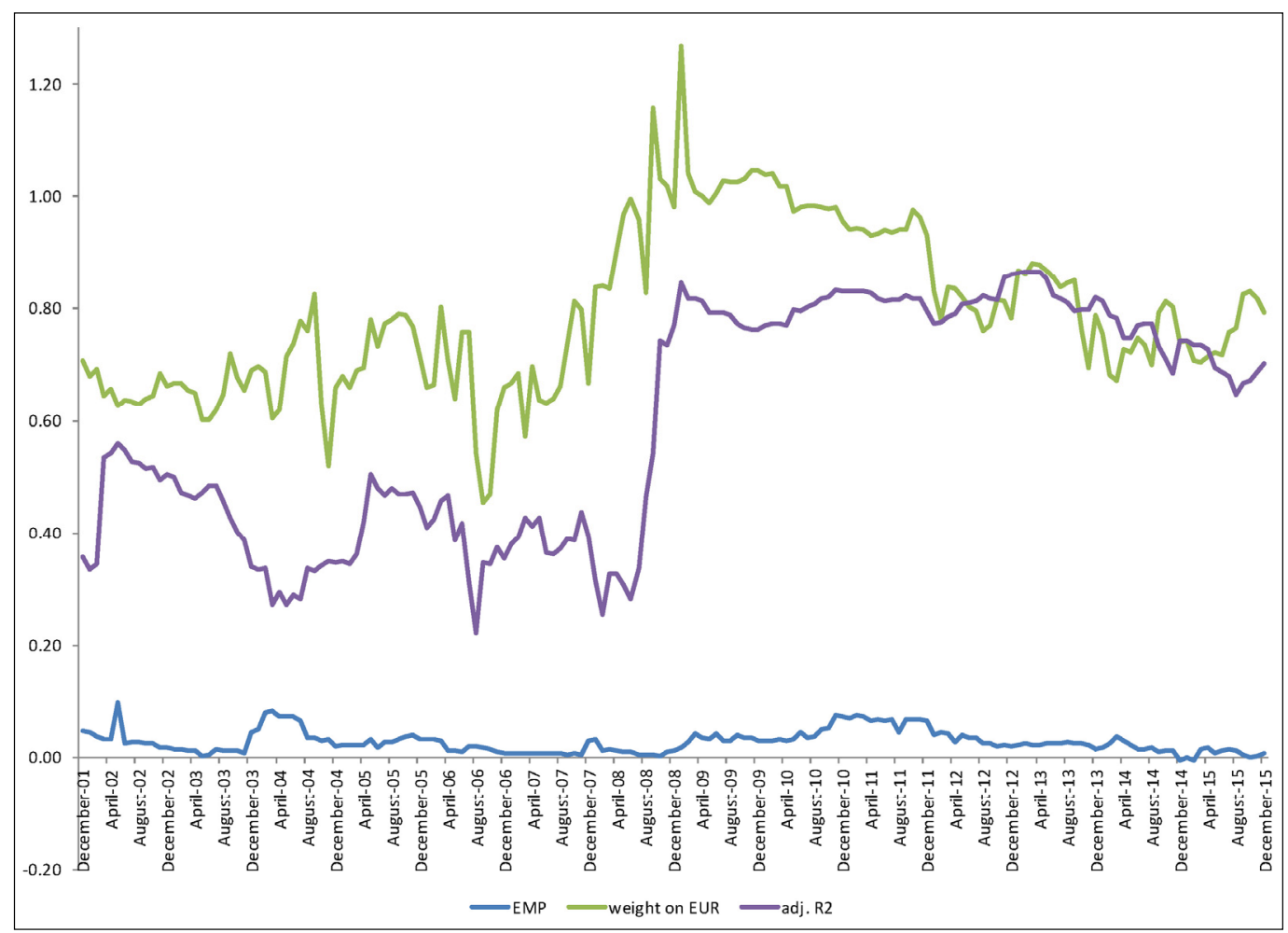

a de facto soft peg to the euro for the median country over most of the sample period.

Figure 4 covers the three Central European inflation targeters (the Czech Republic, Hungary, and Poland). The story that emerges from that figure is qualitatively similar, if noisier. The euro has been an important anchor for monetary policy in these countries, particularly since 2008 . The median adjusted $R^{2}$ also jumped up in 2008. The median EMP coefficient was slightly higher in 2008 2010.

Figure 5 covers the five countries in the CESEE dollar bloc (Belarus, Moldova, Russia, Ukraine, and Turkey). The US dollar's importance as a monetary anchor in the region appears to have fallen over time. Especially after the end of 2013 and corresponding to macroeconomic turmoil in several of these countries, the median EMP coefficient has jumped up and the median weight on the US dollar has declined. The median adjusted $R^{2}$ has trended downward over the entire period. 
Figure 4. Median basket weight on the EUR, median EMP, and median adjusted $R^{2}$ from 36-month rolling regressions for three central european inflation targeters, 1999 2015

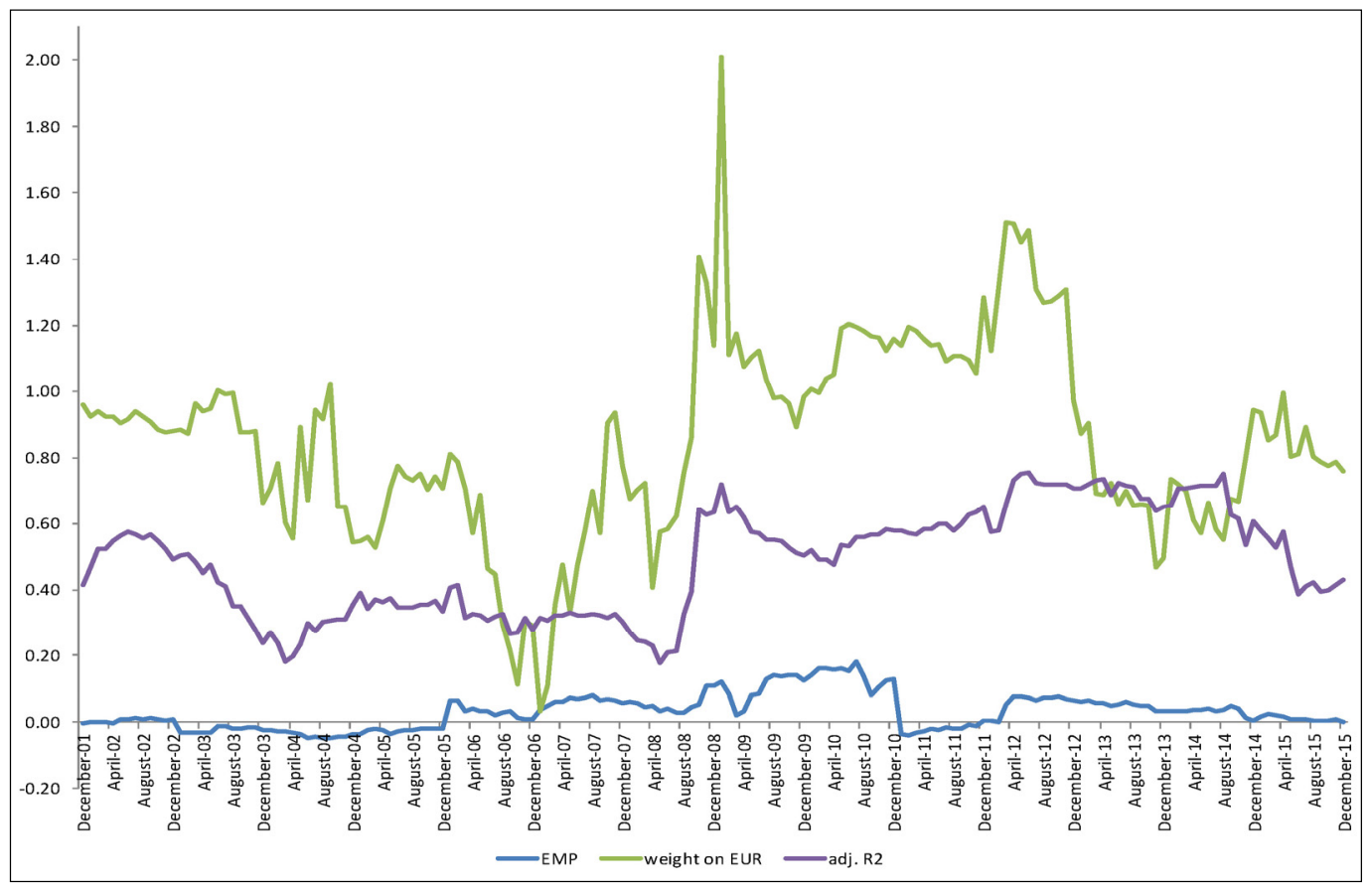

Figure 5. Median basket weight on the US dollar, median EMP, and median adjusted $R^{2}$ from 36-month rolling regressions for five countries in CESEE dollar bloc, 1999 2015

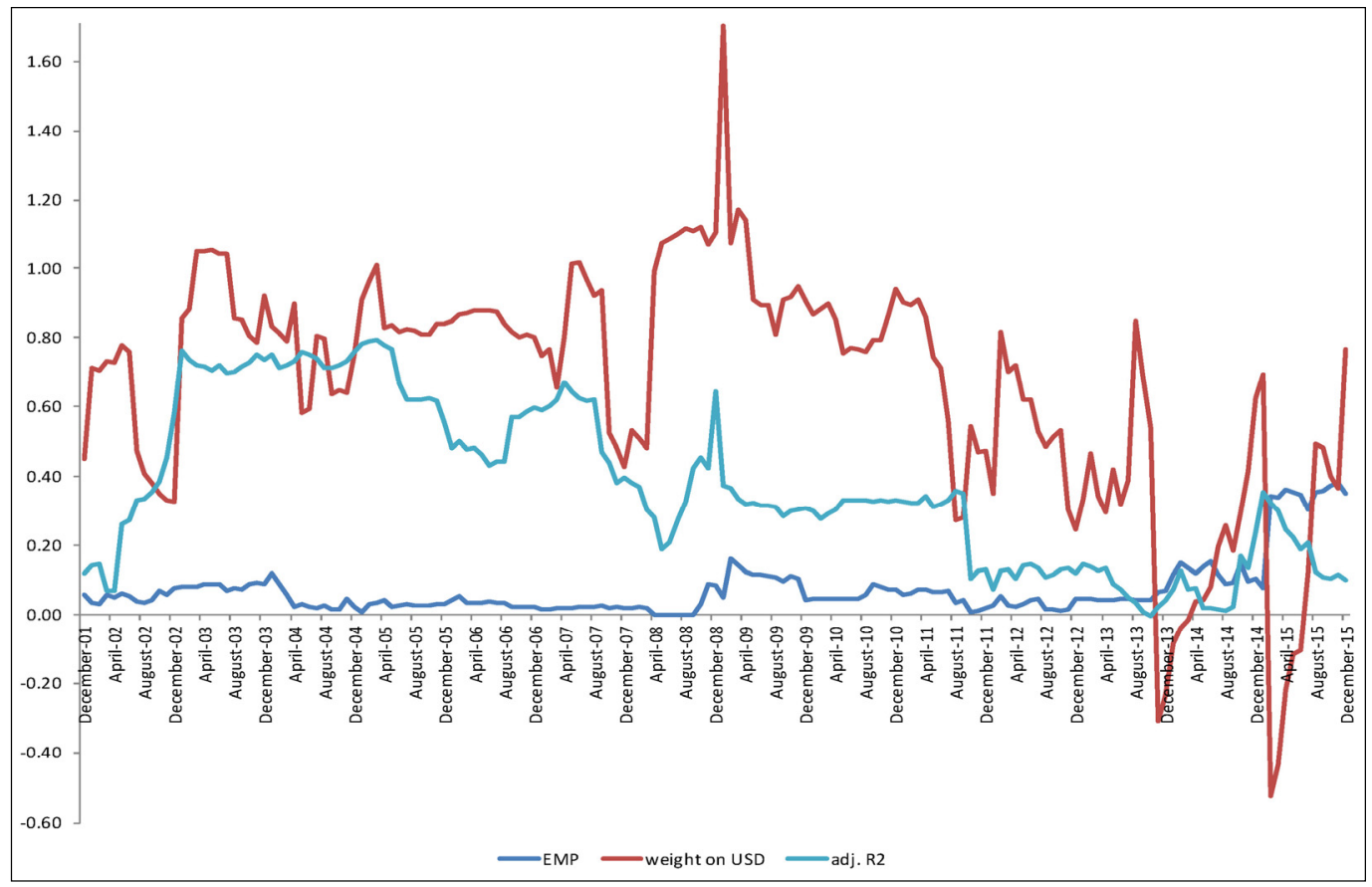




\section{Robustness checks}

This section describes results from two robustness checks. First, it is possible that the response of the domestic currency to appreciations and depreciations of the major currencies is asymmetric. To test this hypothesis, I supplemented Equation (1) with three dummy variables, each of which equals one during those periods when the US dollar (or the euro or the British pound) depreciated against the $S D R$, and zero otherwise. More importantly, I supplemented Equation (1) with three interaction terms of each dummy with $\varepsilon_{U S D / S D R}, \varepsilon_{E U R / S D R}$, and $\varepsilon_{G B P / S D R}$, respectively. Furthermore, Equation (1) was supplemented with three additional interaction terms of each currency dummy with $E M P$ to test for the possibility that EMP coefficients differ in appreciation versus depreciation episodes (A dummy and interaction terms for the Russian ruble for Belarus, Moldova, and Ukraine are also included).

The results (available upon request) reveal that the basket weights in certain countries tend to respond more strongly to depreciations in major currencies than to appreciations. This is the case for the Czech Republic, Hungary, and Belarus with respect to the euro; Ukraine with respect to the British pound; and Belarus and Moldova with respect to the Russian ruble. Regarding interaction terms with the EMP variable, only about 10 percent of the coefficients on those were statistically significant (at the 10 percent level of significance). This is what one would expect if the results were driven entirely by sampling variation. Thus, it is reasonable to conclude that there is no evidence of an asymmetry in EMP with respect to appreciations and depreciations in major currencies.

Second, a possible criticism of the model described in Equations (1) and (2) is that it takes a narrow view of exchange market pressure. In addition to the stock of international reserves, interest rates may also play the role of a shock absorber. An alternative way to define EMP to account for this possibility would be:

$$
E M P \equiv-\frac{1}{100 \sigma_{1}}\left(\frac{(\triangle G I R}{R M}\right)+\frac{1}{100 \sigma_{2}} \Delta\left(i-i^{*}\right)
$$

In the above Equation, $i$ and $i^{*}$ denote the domestic and foreign short-term interest rate, respectively.8) $\sigma_{1}$ and $\sigma_{2}$ denote the standard deviations of $\frac{\Delta G I R}{R M}$ and $\Delta\left(i-i^{*}\right)$, respectively. 100 is a scaling factor.

EMP now is a weighted average of the change in the stock of gross international reserves and the change in the short-term interest premium, both weighted by the inverse of their

8) I typically used money market or $T$-bill interest rates. When these were not available, I used policy or discount rates. For $i^{*}$, I used euro area interest rates for the eight countries that track the euro and the US interest rates for the five countries that track the US dollar. 
respective standard deviations. If there is a negative shock to the demand for domestic currency, we would expect it to show up as exchange rate depreciation, as a reduction in international reserves, or as an increase in the interest rate spread. The regression coefficient $\beta_{1}$ would then measure the extent to which market pressure on the domestic currency is allowed to be reflected in the exchange rate, as opposed to the stock of international reserves or domestic short-term interest rates.

Tables 8 to 10 re-estimate the results for the 13 countries in Emerging Europe plus Bulgaria and South Africa for 1999 2015. The results are quite similar to those reported in Tables 5 to 7. The EMP coefficients are much higher than they were in Tables 5 to 7 , but the scale is different here.

Table 8. Regression Results for Five Balkan Countries, 1999 2015

\begin{tabular}{|c|c|c|c|c|c|c|c|c|}
\hline Variables Country & $\begin{array}{c}\text { (1) } \\
\text { HRV }\end{array}$ & $\begin{array}{c}(2) \\
\text { MKD }\end{array}$ & $\begin{array}{c}(3) \\
\text { ALB }\end{array}$ & $\begin{array}{c}(4) \\
\text { ROM }\end{array}$ & $\begin{array}{c}(5) \\
\text { SRB }\end{array}$ & Median & $\begin{array}{c}\text { (6) } \\
\text { BGR }\end{array}$ & $\begin{array}{c}(7) \\
\text { ZAF }\end{array}$ \\
\hline \multirow[t]{2}{*}{ Constant } & 0.00 & 0.00 & -0.00 & $0.00 * *$ & $0.00 * *$ & 0.00 & -0.00 & $0.01 * *$ \\
\hline & $(0.00)$ & $(0.00)$ & $(0.00)$ & $(0.00)$ & $(0.00)$ & & $(0.00)$ & $(0.00)$ \\
\hline \multirow[t]{2}{*}{ EMP } & $0.22 * *$ & 0.05 & 0.18 & 0.24 & 0.19 & 0.19 & 0.00 & $0.67 * * *$ \\
\hline & $(0.09)$ & $(0.04)$ & $(0.14)$ & $(0.18)$ & $(0.12)$ & & $(0.01)$ & $(0.22)$ \\
\hline \multirow[t]{2}{*}{$\varepsilon_{U S D / S D R}$} & -0.05 & 0.02 & 0.19 & $0.57 * *$ & 0.29 & 0.19 & 0.00 & 0.04 \\
\hline & $(0.14)$ & $(0.10)$ & $(0.17)$ & $(0.28)$ & $(0.23)$ & & $(0.03)$ & $(0.38)$ \\
\hline \multirow[t]{2}{*}{$\varepsilon_{E U R / S D R}$} & $0.76 * * *$ & $0.93 * * *$ & $0.83 * * *$ & $1.24 * * *$ & $1.32 * * *$ & 0.93 & $1.03 * * *$ & $0.54 *$ \\
\hline & $(0.09)$ & $(0.08)$ & $(0.14)$ & $(0.26)$ & $(0.17)$ & & $(0.03)$ & $(0.28)$ \\
\hline \multirow[t]{2}{*}{$\varepsilon_{G B P / S D R}$} & 0.07 & -0.03 & 0.07 & $0.20 * *$ & 0.09 & 0.07 & -0.00 & 0.24 \\
\hline & $(0.05)$ & $(0.05)$ & $(0.07)$ & $(0.09)$ & $(0.11)$ & & $(0.02)$ & $(0.21)$ \\
\hline Observations & 183 & 203 & 174 & 172 & 146 & 174 & 204 & 204 \\
\hline Adjusted $R^{2}$ & 0.63 & 0.76 & 0.49 & 0.44 & 0.53 & 0.53 & 0.95 & 0.08 \\
\hline
\end{tabular}

(Notes) Columns ( 1 to 7 ) estimate Equation (1) in the main text of the paper. The dependent variable is the percentage change in the country's exchange rate with the SDR. EMP is defined in Equation (3) in the main text of the paper. $\mathcal{E}_{U S D / S D R}$ is the percentage change in the US dollar's exchange rate with the SDR. The remaining independent variables are defined similarly for the euro and the British pound. Robust standard errors are reported in parentheses. $* * *, * *$, and $*$ denote statistical significance at the $1 \%, 5 \%$, and $10 \%$ level, respectively. 
Table 9. Regression results for three central european inflation targeters, 1999 2015

\begin{tabular}{|c|c|c|c|c|c|c|}
\hline Variables & $\begin{array}{c}\text { (1) } \\
\text { CZE }\end{array}$ & $\begin{array}{c}(2) \\
\text { HUN }\end{array}$ & $\begin{array}{c}\text { (3) } \\
\text { POL }\end{array}$ & Median & $\begin{array}{c}\text { (4) } \\
\text { BGR }\end{array}$ & $\begin{array}{c}\text { (5) } \\
\text { ZAF }\end{array}$ \\
\hline \multirow[t]{2}{*}{ Constant } & -0.00 & 0.00 & 0.00 & 0.00 & -0.00 & $0.01 * *$ \\
\hline & $(0.00)$ & $(0.00)$ & $(0.00)$ & & $(0.00)$ & $(0.00)$ \\
\hline \multirow[t]{2}{*}{ EMP } & -0.17 & 0.08 & 0.17 & 0.08 & 0.00 & $0.67 * * *$ \\
\hline & $(0.12)$ & $(0.15)$ & $(0.18)$ & & $(0.01)$ & $(0.22)$ \\
\hline \multirow[t]{2}{*}{$\varepsilon_{U S D / S D R}$} & -0.23 & -0.00 & 0.10 & 0.00 & 0.00 & 0.04 \\
\hline & $(0.16)$ & $(0.26)$ & $(0.35)$ & & $(0.03)$ & $(0.38)$ \\
\hline \multirow[t]{2}{*}{$\varepsilon_{E U R / S D R}$} & $0.99 * * *$ & $1.30 * * *$ & $1.02 * * *$ & 1.02 & $1.03 * * *$ & $0.54 *$ \\
\hline & $(0.12)$ & $(0.28)$ & $(0.27)$ & & $(0.03)$ & $(0.28)$ \\
\hline \multirow[t]{2}{*}{$\varepsilon_{G B P / S D R}$} & 0.19 & $0.25^{* *}$ & $0.37 * *$ & 0.25 & -0.00 & 0.24 \\
\hline & $(0.13)$ & $(0.10)$ & $(0.16)$ & & $(0.02)$ & $(0.21)$ \\
\hline Observations & 202 & 196 & 204 & 202 & 204 & 204 \\
\hline Adjusted $R^{2}$ & 0.61 & 0.52 & 0.34 & 0.52 & 0.95 & 0.08 \\
\hline
\end{tabular}

(Notes) Columns ( 1 to 5 ) estimate Equation (1) in the main text of the paper. The dependent variable is the percentage change in the country's exchange rate with the SDR. EMP is defined in Equation (3) in the main text of the paper. $\varepsilon_{U S D / S D R}$ is the percentage change in the US dollar's exchange rate with the SDR. The remaining independent variables are defined similarly for the euro and the British pound. Robust standard errors are reported in parentheses. $* * *, * *$, and $*$ denote statistical significance at the $1 \%, 5 \%$, and $10 \%$ level, respectively.

Table 10. Regression results for the dollar bloc, 1999 2015

\begin{tabular}{|c|c|c|c|c|c|c|c|c|}
\hline Variables & $\begin{array}{c}(1) \\
\text { BLR }\end{array}$ & $\begin{array}{c}(2) \\
\text { MDA }\end{array}$ & $\begin{array}{c}\text { (3) } \\
\text { RUS }\end{array}$ & $\begin{array}{c}(4) \\
\text { TUR }\end{array}$ & $\begin{array}{c}\text { (5) } \\
\text { UKR }\end{array}$ & Median & $\begin{array}{c}\text { (6) } \\
\text { BGR }\end{array}$ & $\begin{array}{c}\text { (7) } \\
\text { ZAF }\end{array}$ \\
\hline \multirow[t]{2}{*}{ Constant } & $0.01 * * *$ & 0.00 & $0.01 * * *$ & 0.01 & $0.00 *$ & 0.01 & -0.00 & $0.01 * *$ \\
\hline & $(0.00)$ & $(0.00)$ & $(0.00)$ & $(0.00)$ & $(0.00)$ & & $(0.00)$ & $(0.00)$ \\
\hline \multirow[t]{2}{*}{ EMP } & 0.12 & 0.17 & $0.63 * * *$ & 1.01 & $0.32 *$ & 0.32 & 0.00 & $0.67 * * *$ \\
\hline & $(0.28)$ & $(0.18)$ & $(0.22)$ & $(0.73)$ & $(0.17)$ & & $(0.01)$ & $(0.22)$ \\
\hline \multirow[t]{2}{*}{$\varepsilon_{U S D / S D R}$} & $0.90 * *$ & 0.36 & $0.56^{*}$ & $1.10 * *$ & $1.31 * * *$ & 0.90 & 0.00 & 0.04 \\
\hline & $(0.41)$ & $(0.26)$ & $(0.30)$ & $(0.49)$ & $(0.20)$ & & $(0.03)$ & $(0.38)$ \\
\hline \multirow[t]{2}{*}{$\varepsilon_{E U R S D R}$} & 0.48 & -0.05 & 0.51 & $1.01 * *$ & 0.21 & 0.48 & $1.03 * * *$ & $0.54 *$ \\
\hline & $(0.42)$ & $(0.16)$ & $(0.34)$ & $(0.42)$ & $(0.24)$ & & $(0.03)$ & $(0.28)$ \\
\hline \multirow[t]{2}{*}{$\varepsilon_{G B P / S D R}$} & $-0.27 * *$ & $-0.19 * *$ & $0.39 * *$ & 0.37 & $0.66 * * *$ & 0.37 & -0.00 & 0.24 \\
\hline & $(0.12)$ & $(0.10)$ & $(0.18)$ & $(0.24)$ & $(0.25)$ & & $(0.02)$ & $(0.21)$ \\
\hline \multirow[t]{2}{*}{$\varepsilon_{R U B / S D R}$} & $0.65^{* * *}$ & $0.21 * *$ & & & 0.04 & 0.21 & & \\
\hline & $(0.14)$ & $(0.08)$ & & & $(0.09)$ & & & \\
\hline Observations & 126 & 191 & 190 & 158 & 156 & 158 & 204 & 204 \\
\hline Adjusted $R^{2}$ & 0.59 & 0.18 & 0.13 & 0.07 & 0.43 & 0.18 & 0.95 & 0.08 \\
\hline
\end{tabular}

(Notes) Columns ( 1 to 7 ) estimate Equation (1) in the main text of the paper. The dependent variable is the percentage change in the country's exchange rate with the SDR. EMP is defined in Equation (3) in the main text of the paper. $\varepsilon_{U S D / S D R}$ is the percentage change in the US dollar's exchange rate with the SDR. The remaining independent variables are defined similarly for the euro, the British pound, and the Russian ruble. Robust standard errors are reported in parentheses. ${ }^{* *},{ }^{* *}$, and $*$ denote statistical significance at the $1 \%, 5 \%$, and $10 \%$ level, respectively. 


\section{Is Exchange Rate Stability in Emerging Europe Natural or Policy-driven?}

The statistical analysis in section III reveals that most of the countries in CESEE closely track the euro or the US dollar. This section considers several possible explanations for this phenomenon.

\section{A. Is exchange rate stability a natural manifestation of inflation targeting?}

Previous empirical studies indicate that small open economies have a high exchange rate pass-through. In other words, price levels in these countries are more responsive to exchange rate fluctuations. Given the higher pass-through, central banks will pay more attention to the exchange rate and could try to stabilize it, even if the ultimate objective is an inflation target. In other words, in a country with a high exchange rate pass-through, inflation targeting could be observationally equivalent to limited exchange rate flexibility.

However, that argument does not seem to apply for the eight CESEE countries that key on the euro. Figure 6 plots their median inflation rates and compares them to the median inflation rates of nine countries in Emerging Europe that have abandoned the exchange rate as a tool for macroeconomic adjustment (Bosnia and Herzegovina, Bulgaria, Estonia, Kosovo, Latvia, Lithuania, Montenegro, Slovakia, and Slovenia). There is a clear contrast in the inflation performance in the run-up to the Global Financial Crisis and its immediate aftermath, when the eight countries with floating exchange rates experienced somewhat less volatile inflation rates. More recently, however, there has been surprisingly little difference in median inflation outcomes between the two groups. The eight CESEE de jure floaters have consistently undershot their inflation targets. In this recent episode, inflation targeting is not observationally equivalent to "fear of floating," and these eight countries appear to have chosen exchange rate stability over their inflation targets.

Figure 7 breaks these eight countries into two groups: five Balkan countries and three Central European inflation targeters. Once again, there is a meaningful difference in their inflation performance in the run-up to the Global Financial Crisis and its immediate aftermath along predictable lines; and once again, more recently, there has been surprisingly little difference in median inflation outcomes among the three groups in Figure 7. 
Figure 6. Median inflation rates for eight De Jure floaters and nine peggers in CESEE (2004 2015)

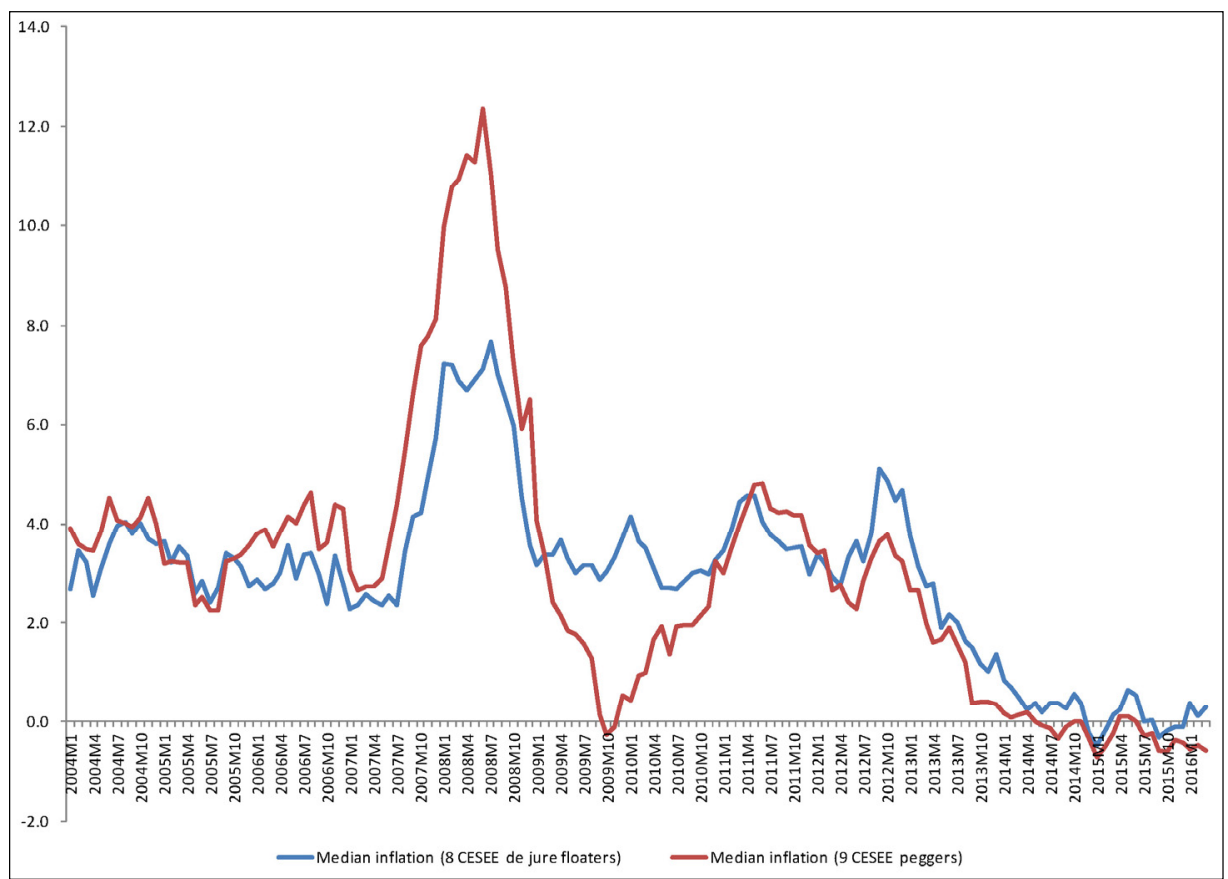

(Source) IMF's International Financial Statistics database.

Figure 7. Median inflation rates for nine CESEE peggers, three central european inflation targeters, and five balkan countries (2004 2015)

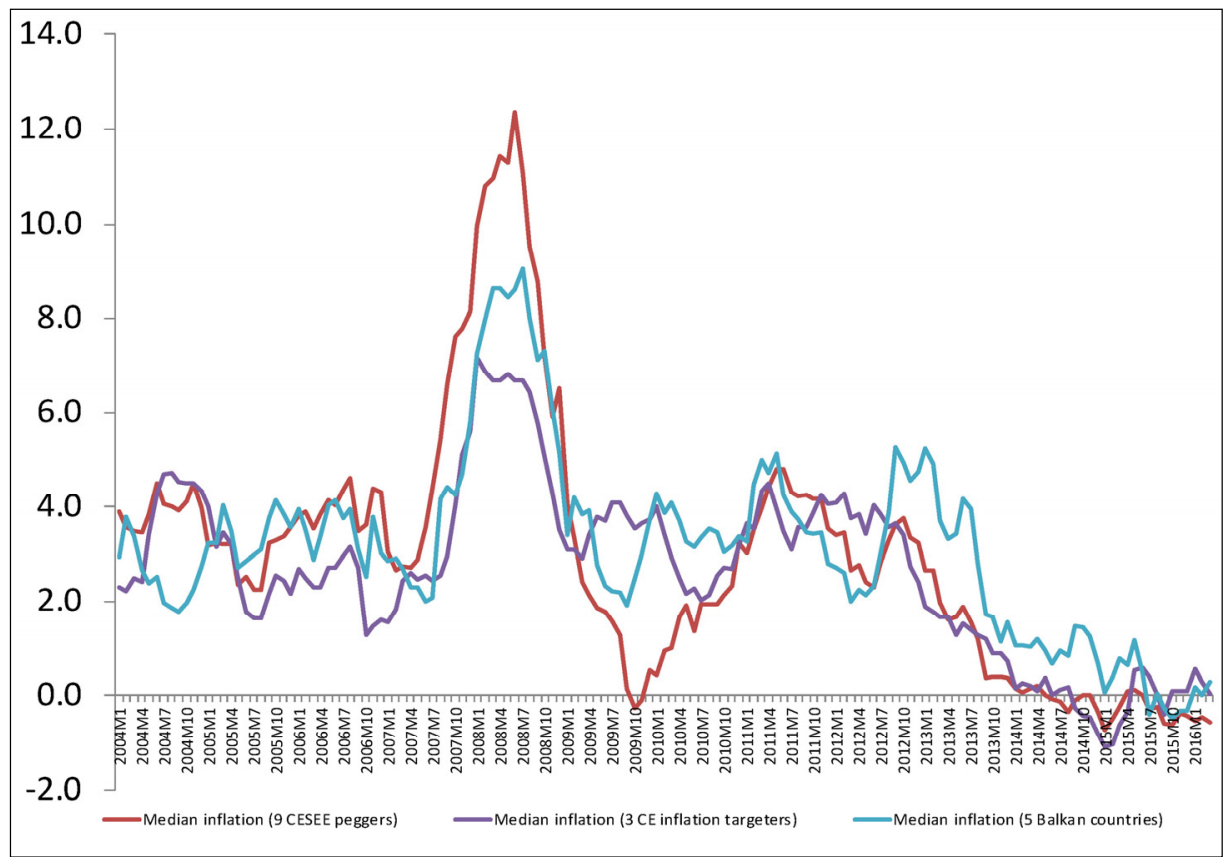

(Source) IMF's International Financial Statistics database. 


\section{B. Is exchange rate stability a consequence of trade integration?}

This section investigates whether the extent to which the 13 CESEE countries track the euro and US dollar makes sense, given the currency structure of their external trade. Figure 8 below shows that countries that traded extensively with the euro area also tend to track the euro quite closely. The figure clearly illustrates the existence of a euro and a dollar bloc in Emerging Europe. The countries in the CESEE dollar bloc lie close to the 45-degree line (with the exception of Belarus, an outlier), so the amount of attention they pay to the euro roughly matches the euro area's importance as a trading partner. However, all countries in Emerging Europe's euro bloc lie above the 45-degree line, so the euro's weight in their exchange rate regimes exceeds the euro area's trade share.

A legitimate critique of Figure 8 could be that by focusing on trade with the euro area, it understates the euro's importance in global trade. Many countries outside the euro area peg to the euro or invoice their exports in euros (particularly in Emerging Europe). Table 11 below tackles this criticism by examining the correlation between each country's NEER and the US dollar-euro exchange rate from 2010 to 2015.

NEERs are based on trade weights, by construction.9) If the euro's weight in a CESEE country's exchange rate regime is "just right," that is, it equals its trade weight (defined broadly to include trading partners whose currencies are pegging to the euro), we would expect the country's NEER to stay constant over time. Therefore, its correlation coefficient with the US dollar-euro exchange rate should be zero. On the other hand, if we found the correlation coefficient to be positive, then the country's NEER tends to appreciate precisely when the euro strengthens against the US dollar. Such a result would be evidence that the euro's weight in the country's exchange rate regime is higher than its trade weight, defined broadly. Vice versa, if we found the correlation coefficient to be negative, then its NEER tends to appreciate precisely when the US dollar strengthens against the euro, suggesting that the US dollar's weight in the country's exchange rate regime is higher than its trade weight.

Table 11 presents the correlation coefficients between the monthly rate of change in the US dollar-euro exchange rate and the NEER monthly rates of change for 13 countries in Emerging Europe for 2010 2015. For six out of eight countries in the CESEE euro bloc, this correlation is both positive and statistically significant when using a simple $t$ test. Following the logic above, the weight that these countries place on the euro in their de facto exchange rate regimes exceeds its trade weight, broadly defined. The only exceptions are Albania and Croatia, whose correlation coefficients are statistically insignificant, indicating that the weight

9) $N E E R \equiv E_{1}^{\frac{\text { Trade }_{1}}{\text { Total Trade }}} E_{2}^{\frac{\text { Trade }_{2}}{\text { Total Trade }}} \ldots E_{N}^{\frac{\text { Trade }_{N}}{\text { Total Trade }}}$

Note that NEER calculations use weights based on trade in goods, so NEERs exclude other important components of the current account, such as trade in services or remittances. 
Figure 8. Estimated basket weight on the euro for 2010 2015 versus share of trade with euro area in total trade for 2010 2014 for 13 CESEE countries

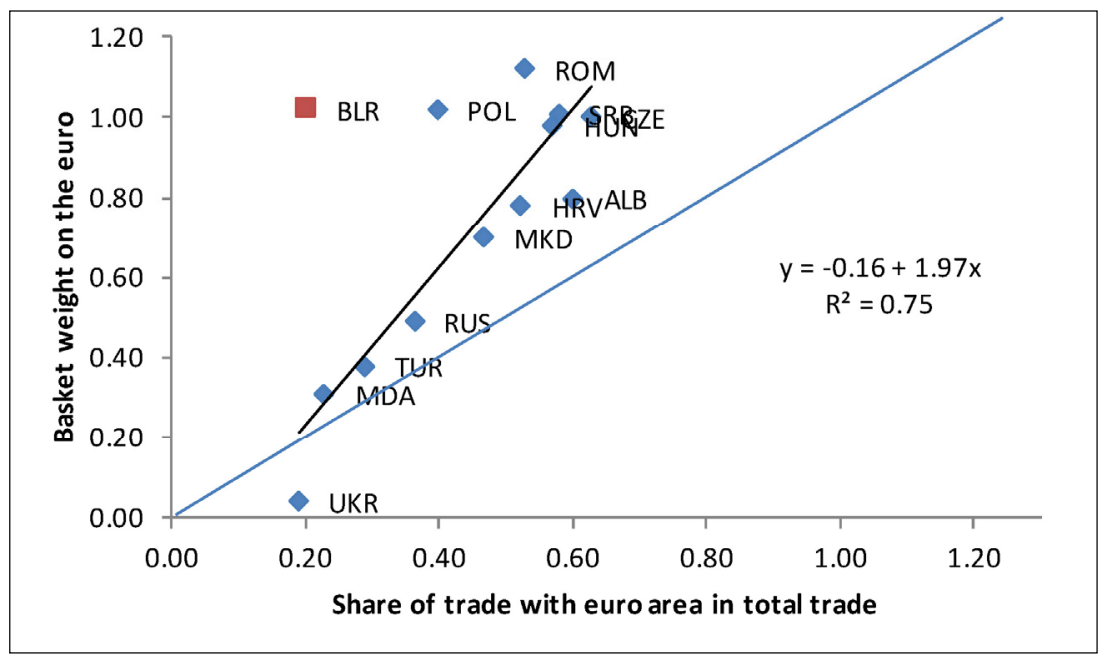

(Note) Share of trade is defined as the weighted average of import and export shares. The basket weight on the euro is an estimate of $\beta_{3}$ in Equation (1). Belarus was excluded from the ordinary least squares estimation as its basket weight on the euro is a statistically insignificant outlier.

(Source) IMF's Direction of Trade Statistics database.

Table 11. Correlation between monthly changes in a country's NEER and US dollar-euro exchange Rate (2010 2015)

\begin{tabular}{lc}
\hline Country & Correlation coefficient \\
\hline CESEE euro bloc & -0.05 \\
Albania & 0.18 \\
Croatia & $0.39^{* * *}$ \\
Czech Republic & $0.31^{* * *}$ \\
Hungary & $0.23^{*}$ \\
North Macedonia & $0.43^{* * *}$ \\
Poland & $0.43^{* * *}$ \\
Romania & $0.35^{* * *}$ \\
Serbia & \\
CESEE dollar bloc & 0.00 \\
Belarus & $-0.26^{* *}$ \\
Moldova & 0.02 \\
Russia & $-0.28^{* * *}$ \\
Turkey & -0.19 \\
\hline Ukraine & \\
\hline
\end{tabular}

(Note) $* * *, * *$, and $*$ denote statistical significance at the $1 \%, 5 \%$, and $10 \%$ level, respectively, using a simple $t$-test. (Source) IMF's Information Notice System and International Financial Statistics databases.

they place on the euro is close to the euro's trade weight.

For two out of five countries in the CESEE dollar bloc (Moldova and Turkey), the correlation 
coefficients are both negative and significant, indicating that the US dollar's weight in their de facto exchange rate regimes exceeds its trade weight, defined broadly.

For the remaining three countries (Belarus, Russia, Ukraine), the correlation coefficients are not statistically significant. Overall, most of these countries (8 out of 13) appear to stabilize their exchange rates with the euro or the US dollar to an extent inconsistent with merely stabilizing their trade-weighted NEERs.

\section{Is exchange rate stability a product of liability dollarization?}

Many countries in Emerging Europe suffer from pervasive dollarization (or euroization). A high percentage of all loans and deposits in the banking system is FX-denominated. In addition, there is a sizable currency mismatch on the balance sheets of the government, non-financial companies, and households. Though income streams and assets are typically denominated in domestic currency, a significant amount of liabilities is denominated in euros or dollars. A currency depreciation increases the value of liabilities in domestic currency terms and reduces net worth. Therefore, depreciations tend to be associated with financial distress or bankruptcy, rather than the export-led growth, which is emphasized in textbook models. In previous empirical work, liability dollarization is the variable with the strongest correlation to "fear of floating:" Countries with the highest fraction of foreign-denominated liabilities are the least likely to float. Such examples include Hausmann, Panizza, and Stein (2001), Kliatskova and Mikkelsen (2015), and Ebeke and Azangue (2015).

Figure 9a below confirms this results for the sample of CESEE countries for 2010 2015.10) There is a strong negative relationship between the degree of dollarization/euroization in the banking system, as measured by the share of FX loans in total loans, and the estimated EMP coefficient (with EMP defined as in Equation (2)). The higher the degree of loan dollarization/ euroization, the lower the estimated degree of exchange rate flexibility. There is a similar, but substantially weaker, relationship for deposit dollarization/euroization (Figure 9b). Whereas exchange rate stability does appear to be driven by liability dollarization, the latter is not a natural driver of the former. Rather, liability dollarization provides a good reason for why pursuing exchange rate stability is a sensible policy choice.

Figures 10a and 10b below report data on the euro's and the US dollar's shares in the public and publicly guaranteed (PPG) external debt of five countries in Emerging Europe's euro bloc (Albania, Hungary, North Macedonia, Romania, and Serbia). These were the countries for which data were available in the World Bank's Global Development Finance database. As evident, the euro's share drifted up significantly, from a median of around 20 percent in 2001 to a median

10) Given the evidence presented in Figures 3 to 5 of evolving exchange rate regimes, this section focuses on the post-crisis period (2010 2015) to minimize problems caused by structural breaks. 
Figure 9a. Estimated EMP coefficient versus share of FX loans in total loans for 13 CESEE countries (2010 2015)

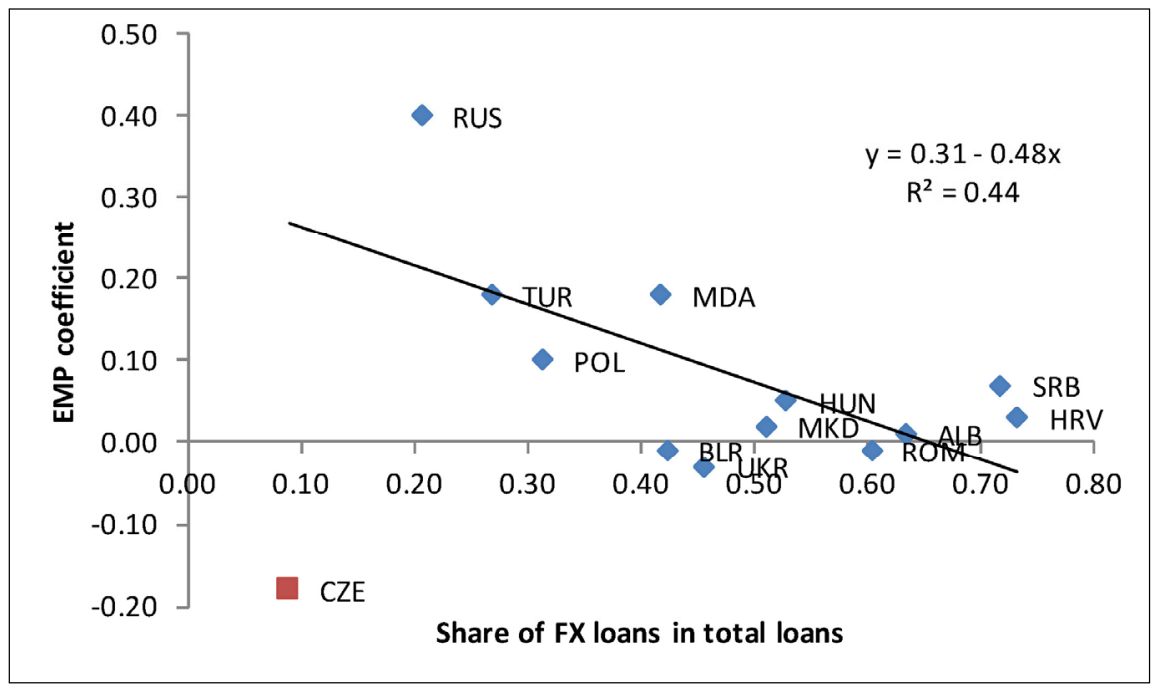

(Note) The Czech Republic was excluded from the ordinary least squares estimation as its EMP coefficient is an outlier.

(Source) Author's estimates, European Bank for Reconstruction and Development data, IMF's International Financial Statistics database.

Figure 9b. Estimated EMP coefficient versus share of FX deposits in total deposits for 13 CESEE countries (2010 2015)

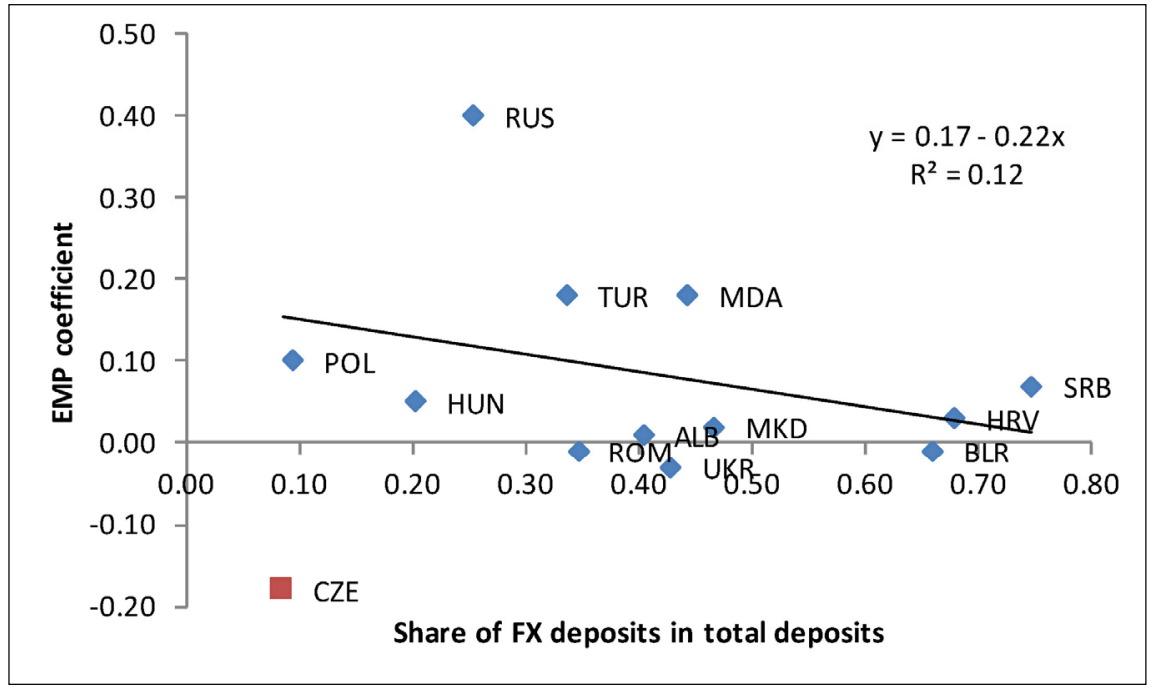

(Note) The Czech Republic was excluded from the ordinary least squares estimation as its EMP coefficient is an outlier.

(Source) Author's estimates, European Bank for Reconstruction and Development data, IMF's International Financial Statistics database. 
Figure 10a. Euro's share in PPG external debt for five countries in CESEE euro bloc, 2001 2013

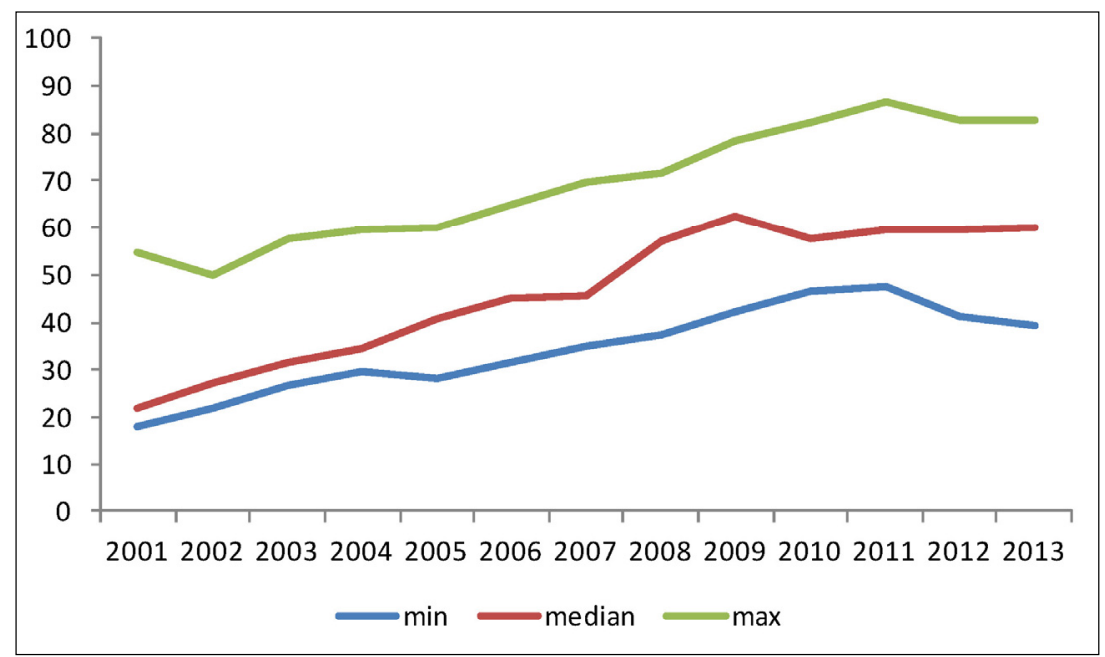

(Note) The countries included are Albania, Hungary, North Macedonia, Romania, and Serbia. (Source) World Bank's Global Development Finance database.

Figure 10b. Dollar's share in PPG external debt for five countries in CESEE euro bloc, 2001 2013

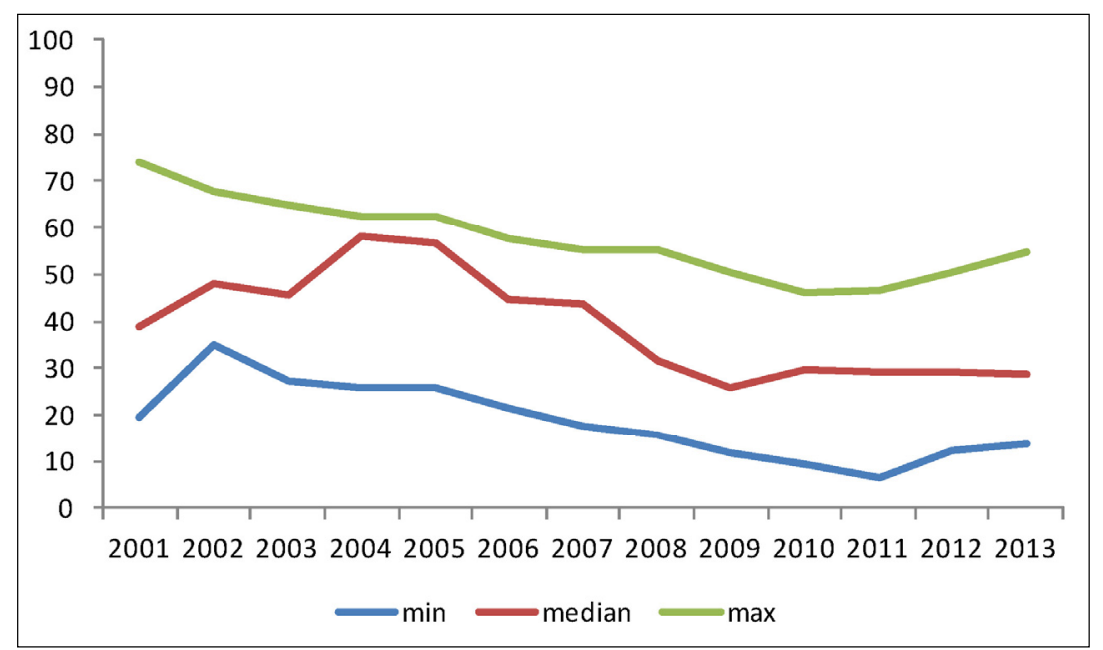

(Note) The countries included are Albania, Hungary, North Macedonia, Romania, and Serbia. (Source) World Bank's Global Development Finance database.

of around 60 percent in 2013. At the same time, the dollar's share gradually decreased, from a median of around 40 percent in 2001 to a median of around 30 percent in 2013.

Figures 11a and 11b below report data on the US dollar's and the euro's shares in the public and public guaranteed (PPG) external debt of four countries in Emerging Europe's dollar bloc 
Figure 11a. US dollar's share in PPG external debt for four countries in CESEE dollar bloc, 2001 2013

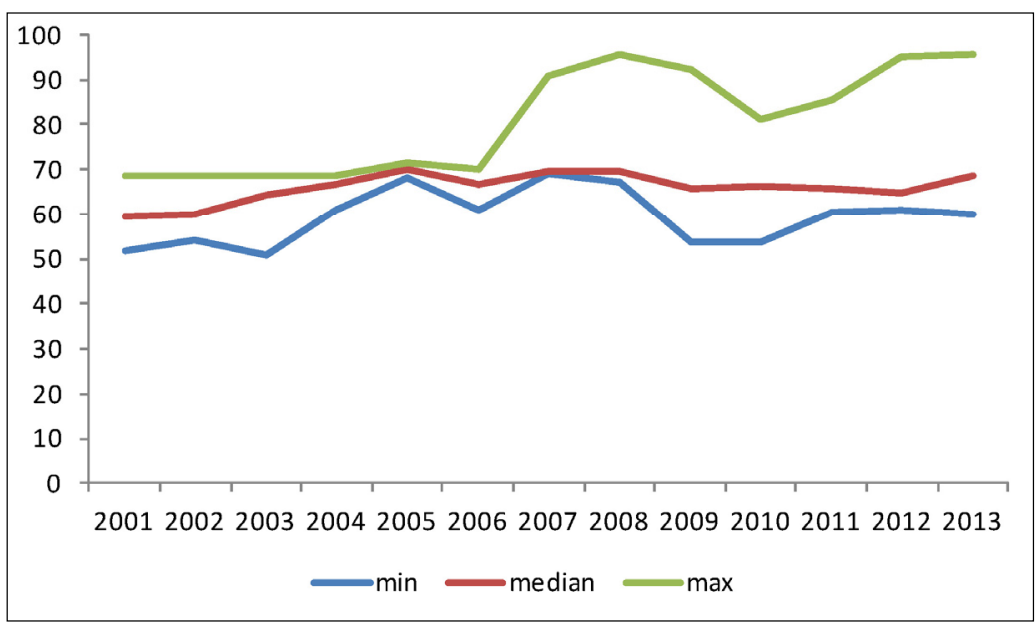

(Note) The countries included are Belarus, Moldova, Turkey, and Ukraine.

(Source) World Bank's Global Development Finance database.

Figure 11b. Euro's share in PPG external debt for four countries in CESEE dollar bloc, 2001 2013

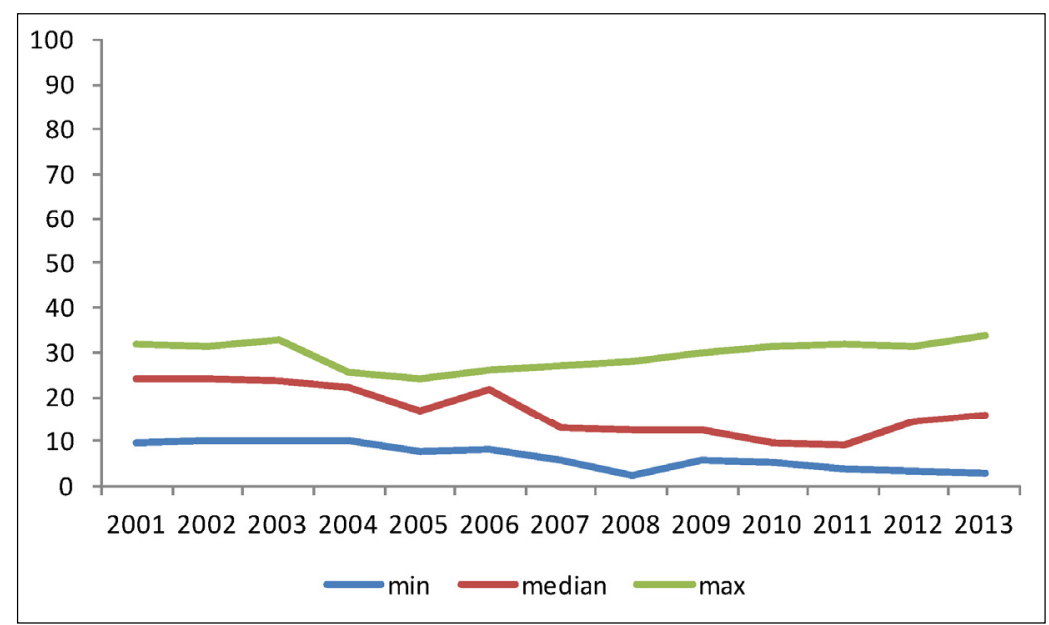

(Note) The countries included are Belarus, Moldova, Turkey, and Ukraine.

(Source) World Bank's Global Development Finance database.

(Belarus, Moldova, Turkey, and Ukraine) for 2001 2013.11) The US dollar's median share drifted up over time from a median of around 60 percent in 2001 to a median of around 70 percent in 2013. The euro fell from a median of around 25 percent in 2001 to a median of around 15 percent in 2013 .

11) Data for Russia were not available in the World Bank's Global Development Finance database. 
Figure 12 below shows a clear positive relationship between the euro's share in PPG external debt and the euro's estimated weight in the exchange rate regimes of the eight countries covered in Figures 10 and 11 (Belarus was excluded as an outlier). The countries in the CESEE dollar bloc lie close to the 45-degree line, so the amount of attention they pay to the euro roughly matches the euro's importance in their PPG external debt. However, the countries in Emerging Europe's euro bloc typically lie above the 45-degree line, so the euro's weight in their exchange rate regimes exceeds the euro's share in their PPG external debt.

Figure 12. Estimated basket weight on the euro for 2010 2015 versus euro's share in PPG external debt for 2010 2013 for nine CESEE countries

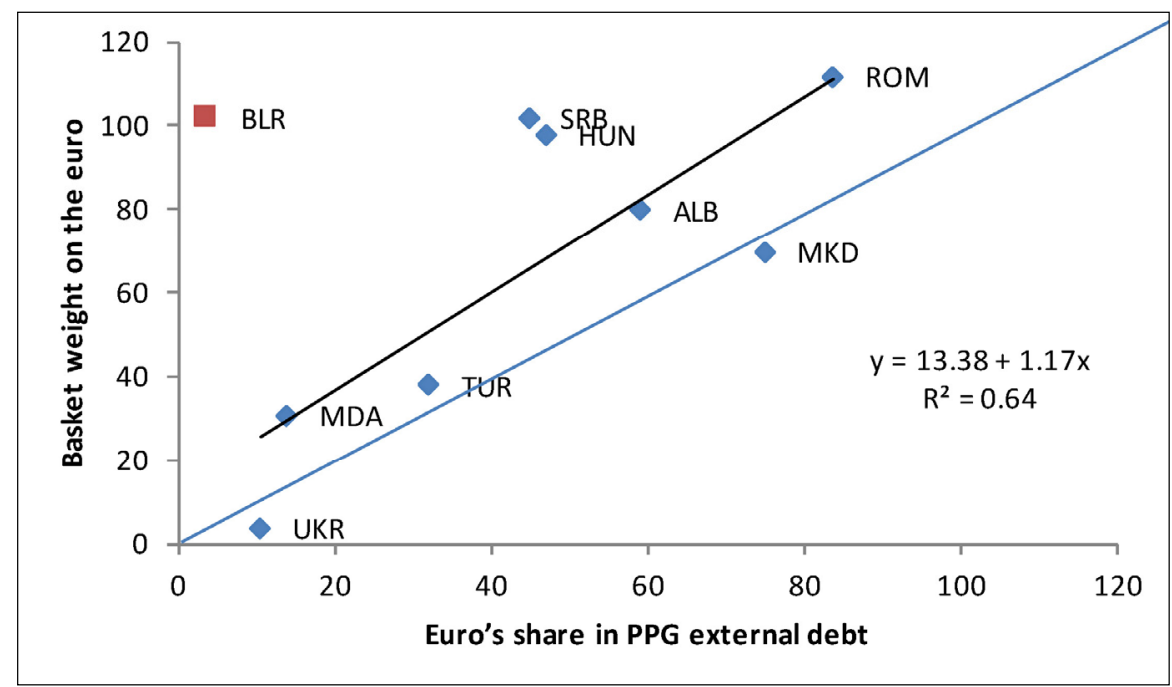

(Note) The basket weight on the euro is an estimate of $\beta_{3}$ in Equation (1). Belarus was excluded from the ordinary least squares estimation as its basket weight on the euro is a statistically insignificant outlier.

(Source) World Bank's Global Development Finance database.

\section{Is exchange rate stability the natural product of business cycle synchronization?}

A final possible explanation is that the apparent exchange rate stability in Emerging Europe might be the natural product of business cycle synchronization. For example, it is possible that the eight current or aspiring EU members in the sample are so highly integrated with the euro area, that they are subject to common shocks. The exchange rate stability with the euro would then be the natural product of economic integration.

To investigate this hypothesis, it would be instructive to compare the eight CESEE countries that track the euro to other countries with floating exchange rates that are tightly integrated with a larger neighbor. Iceland, Norway, Sweden, Switzerland, and the United Kingdom are examples of floaters that are highly integrated with the euro area. Canada and Mexico are 
highly integrated with the US, and so is New Zealand with Australia. Figure 13 below plots the standard deviations of the quarterly changes in the bilateral exchange rates of these countries (with the euro, US dollar, or Australian dollar, as appropriate) against the correlation of their quarterly GDP growth rates with that of the large neighbor's. The figure suggests that there is indeed a negative relationship between the two variables: The higher the degree of business cycle synchronization, the less volatile the bilateral nominal exchange rate. This is an intuitively plausible result.

Figure 13. Standard deviation of quarterly change in bilateral nominal exchange rates versus correlation in quarterly GDP growth rates, 2010 2015

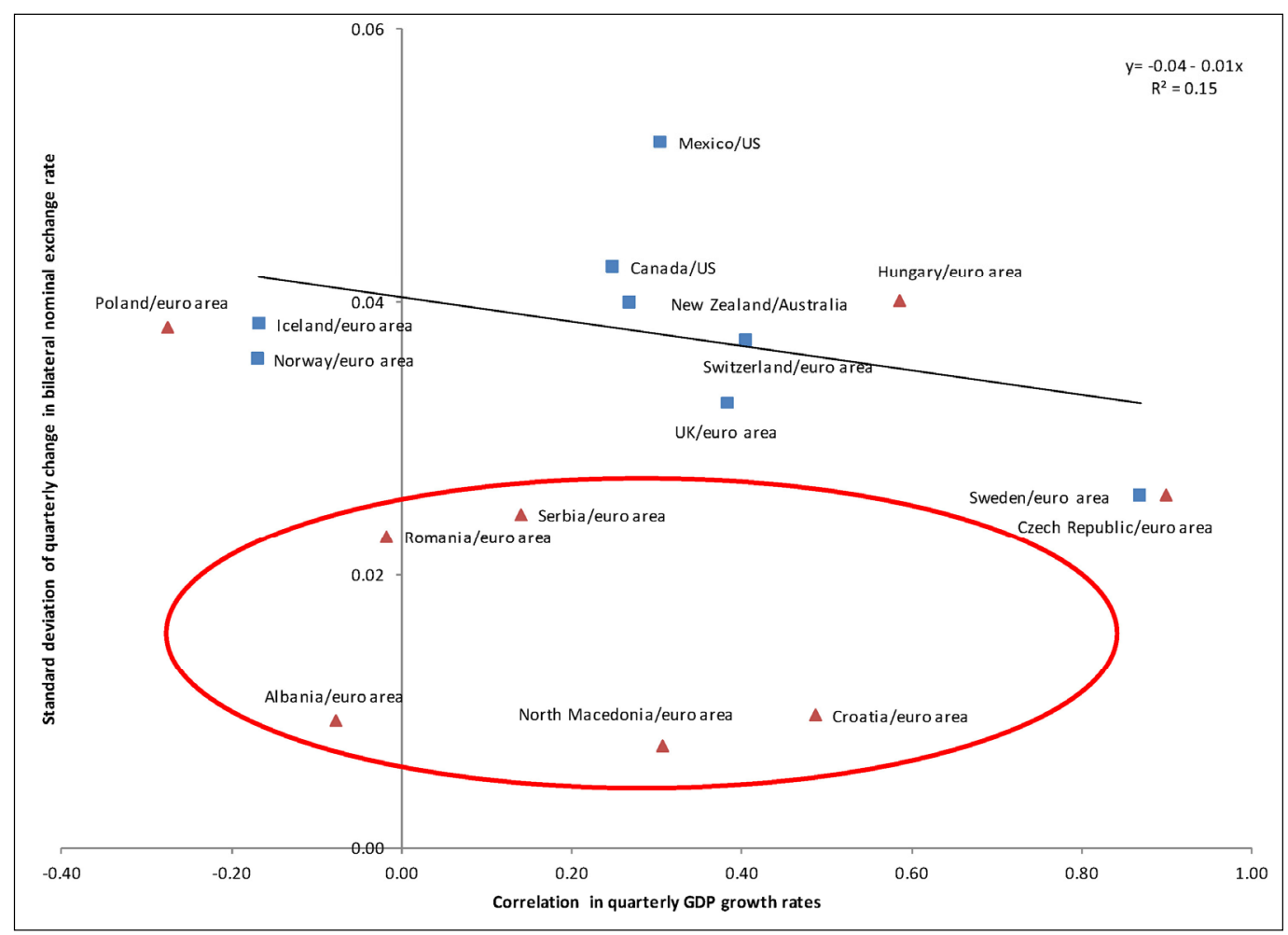

(Source) IMF's International Financial Statistics database.

If we add the eight Emerging Europe countries that were found to track the euro closely, the three Central European inflation targeters (the Czech Republic, Hungary, and Poland) lie fairly close to the regression line. This result indicates that, for these countries, the exchange rate stability with the euro might indeed be the natural product of economic integration and business cycle synchronization. In contrast, the five Balkan countries (Albania, Croatia, North Macedonia, Romania, and Serbia) lie significantly below the regression line. In other words, their exchange rates with the euro are substantially less volatile than one would expect based 
on the extent of their integration with the euro area. For these countries, the exchange rate stability with the euro appears to be a conscious policy choice rather than a natural consequence of business cycle synchronization.

Of course, a simple scatterplot like the one in Figure 13 cannot effectively settle the question of whether exchange rate stability with the euro is the natural product of economic integration and business cycle synchronization. Though there are reasons to be skeptical, as discussed above, this remains an interesting hypothesis that could be explored in future research.

\section{Conclusion}

This paper used the framework pioneered by Frankel and Wei (1994) and extended in Frankel and Wei (2008) to show that most countries in Emerging Europe with de jure floating exchange rate regimes have been tracking the euro or the US dollar quite closely in recent years. In other words, the exchange rate regimes of most of these countries can be approximated by a soft peg to a currency basket dominated by the euro or the US dollar. The extent to which each country's currency tracks the euro or the US dollar is correlated with the currency structure of its external trade and finance. However, some countries appear to track either currency to an extent which appears inconsistent with inflation targeting or trade or financial integration. The phenomenon is particularly pronounced among the countries in the CESEE euro bloc, which may be deliberately gravitating around the euro in anticipation of eventually joining the euro area.

Future research could extend the analysis in this paper in at least three directions. First, we could further pursue the question of whether exchange rate stability with the euro is a natural product of business cycle synchronization. Second, and on a related note, future research could explore the role of financial integration in exposing Emerging Europe to shocks similar to those in the euro area, thus triggering exchange rate stability. Third, a Taylor Rule augmented with an exchange rate factor could be estimated to test the proposition that CESEE countries pursue exchange rate stability as a policy objective, beyond minimizing the output gap or achieving an inflation target.

\section{References}

Calvo, Guillermo, and Carmen Reinhart. (2002). "Fear of Floating." Quarterly Journal of Economics $117,379-408$.

Calvo, Guillermo, and Carmen Reinhart. (2005). "Fixing for your life," in Emerging Capital Markets in Turmoil: Bad Luck or Bad Policy? Guillermo Calvo. Cambridge, MA: MIT Press. 
D'Adamo, Gaetano. (July 2009). Measuring Exchange Rate Flexibility in Europe. Working Paper, Universita di Bologna.

Ebeke, Christian, and Armand Fouejieu Azangue. (October 2015). Inflation Targeting and Exchange Rate Regimes in Emerging Markets. IMF Working Paper 15/228.

Frankel, Jeffrey, and Shang-Jin Wei. (1994). "Yen Bloc or Dollar Bloc? Exchange Rate Policies of the East Asian Economies," in Macroeconomic Linkages: Savings, Exchange Rates, and Capital Flows. Takatoshi Ito and Anne Krueger, eds. Chicago: University of Chicago Press, 295-329.

Frankel, Jeffrey, and Shang-Jin Wei. (2008). "Estimation of De Facto Exchange Rate Regimes: Synthesis of the Techniques for Inferring Flexibility and Basket Weights." IMF Staff Papers 55, no. 3, 384-416.

Hausmann, Ricardo, Ugo Panizza, and Ernesto Stein. (2001). "Why Do Countries Float the Way They Float?" Journal of Development Economics 66, 387-414.

Kliatskova, Tatsiana, and Uffe Mikkelsen. (December 2015). Floating with a Load of FX Debt? IMF Working Paper 15/284.

Mussa, Michael. (Autumn 1986). "Nominal Exchange Rate Regimes and the Behavior of Real Exchange Rates: Evidence and Implications." Carnegie-Rochester Conference Series on Public Policy 25, 117-214. 